\title{
A low-carbohydrate survey: Evidence for sustainable metabolic syndrome reversal
}

\begin{tabular}{|c|c|}
\hline $\begin{array}{l}\text { Authors: } \\
\text { Mark T. Cucuz } \\
\text { Justin Tondt }{ }^{2} \\
\text { Nancy E. Dock } \\
\text { Laura Saslow } \\
\text { Thomas R. Wc }\end{array}$ & $\begin{array}{l}\text { zella }^{1} \\
\text { ter }^{3} \\
\text { (D) } \\
\operatorname{od}^{5}\end{array}$ \\
\hline $\begin{array}{l}\text { Affiliations: } \\
{ }^{1} \text { Department } \\
\text { Medicine, Jeff } \\
\text { Center, West } \\
\text { University, Un }\end{array}$ & $\begin{array}{l}\text { f Family } \\
\text { erson Medical } \\
\text { /irginia } \\
\text { ited States }\end{array}$ \\
\hline $\begin{array}{l}{ }^{2} \text { Geisinger Co } \\
\text { School of Mec } \\
\text { United States }\end{array}$ & $\begin{array}{l}\text { nmonwealth } \\
\text { licine, }\end{array}$ \\
\hline $\begin{array}{l}{ }^{3} \text { Center for } \mathrm{He} \\
\text { University of } \\
\text { Medical Scien } \\
\text { United States }\end{array}$ & $\begin{array}{l}\text { alth Literacy, } \\
\text { arkansas for } \\
\text { ces, }\end{array}$ \\
\hline $\begin{array}{l}{ }^{4} \text { Department } \\
\text { Behavior and } \\
\text { Sciences, Sch } \\
\text { University of } \\
\text { United States }\end{array}$ & $\begin{array}{l}\text { Biological } \\
\text { ol of Nursing, } \\
\text { Michigan, }\end{array}$ \\
\hline $\begin{array}{l}{ }^{5} \text { Division of } \mathrm{N} \\
\text { Department } 0 \\
\text { University of } \\
\text { United States }\end{array}$ & $\begin{array}{l}\text { onatology, } \\
\text { f Pediatrics, } \\
\text { Nashington, }\end{array}$ \\
\hline $\begin{array}{l}\text { Correspondin } \\
\text { Mark Cucuzze } \\
\text { cucuzzellam@ }\end{array}$ & $\begin{array}{l}\text { g author: } \\
\text { la, } \\
\text { vvumedicine.org }\end{array}$ \\
\hline $\begin{array}{l}\text { Dates: } \\
\text { Received: } 16 \\
\text { Accepted: } 02 \\
\text { Published: } 21\end{array}$ & $\begin{array}{l}\text { ept. } 2017 \\
\text { Vov. } 2017 \\
\text { Dec. } 2017\end{array}$ \\
\hline $\begin{array}{l}\text { How to cite th } \\
\text { Cucuzzella, M } \\
\text { Dockter, N.E., } \\
\text { Wood, T.R., A I } \\
\text { survey: Evider } \\
\text { sustainable m } \\
\text { syndrome rev } \\
\text { resist. } 2017 ; 2 \\
\text { https://doi.or } \\
\text { v2i1.30 }\end{array}$ & $\begin{array}{l}\text { is article: } \\
\text { T., Tondt, T., } \\
\text { Saslow, L., \& } \\
\text { w-carbohydrate } \\
\text { ce for } \\
\text { etabolic } \\
\text { ersal. J. insul. } \\
\text { 1), a30. } \\
\text { /10.4102/jir. }\end{array}$ \\
\hline Read online: & \\
\hline 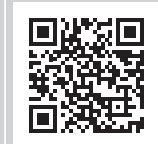 & $\begin{array}{l}\text { Scan this QR } \\
\text { code with your } \\
\text { smart phone or } \\
\text { mobile device } \\
\text { to read online. }\end{array}$ \\
\hline
\end{tabular}

Background: Metabolic syndrome has become a significant problem, with the American Diabetes Association estimating the cost of diabetes and pre-diabetes in the United States alone to be $\$ 322$ billion per year. Numerous clinical trials have demonstrated the efficacy of low-carbohydrate diets in reversing metabolic syndrome and its associated disorders.

Aim: This study was designed to examine how voluntary adherents to a low-carbohydrate diet rate its effectiveness and sustainability using an online survey.

Setting and methods: The 57-question survey was administered online and shared internationally via social media and 'low-carb' communities. Where appropriate, chi-squared tests and paired $t$-tests were used to analyse the responses.

Results: There were 1580 respondents. The majority of respondents had consumed less than $100 \mathrm{~g}$ of carbohydrates per day for over a year, typically for reasons of weight loss or disease management. There was a reported decrease in waist circumference and weight with a simultaneous decrease in hunger and increase in energy level. Of those who provided laboratory values, the majority saw improvements in their $\mathrm{HbA} 1 \mathrm{c}$, blood glucose measurements, and lipid panel results. There was a reduction in usage of various medications, and $25 \%$ reported medication cost savings, with average monthly savings of $\$ 288$ for those respondents. In particular, the usage of pain relievers and antiinflammatories dropped with a simultaneous decreased rating of pain and increase in mobility.

Conclusion: We conclude that low-carbohydrate diets are a sustainable method of metabolic syndrome reversal in a community setting.

\section{Introduction}

The prevalence of obesity and diabetes in the United States and the world has increased dramatically over the last 40 years with no sign of correction. These diseases remain undefeated despite billions of dollars in research and health care costs. ${ }^{1}$ Estimates from the Centers for Disease Control and Prevention (CDC) and National Health and Nutrition Examination Survey (NHANES) indicate that two-thirds of adults are overweight (body mass index $(\mathrm{BMI}) \geq 25 \mathrm{~kg} / \mathrm{m}^{2}$ ), ${ }_{1}^{2,3}$ with $36 \%$ being obese $\left(\mathrm{BMI} \geq 30 \mathrm{~kg} / \mathrm{m}^{2}\right) .{ }^{4}$ The CDC's review of 2015 data reported more than 114 million Americans have diabetes or pre-diabetes. ${ }^{5}$ While the rate of new diagnoses remains steady, the report noted that $9.4 \%$ (30.3 million of the 114 million estimated) of the US population has diabetes - an increase from 29.1 million in 2014. Countries with historically low diabetes rates are also now affected: almost half the population of China has pre-diabetes, and $10 \%$ have the diabetes. ${ }^{6}$ The medical costs of diabetes and its complications and co-morbidities are staggering. The American Diabetes Association (ADA) estimates the cost of diabetes and pre-diabetes in the United States

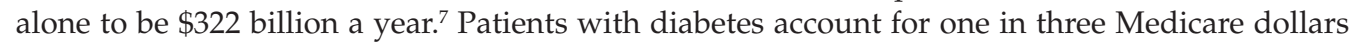
spent and one in five overall health care dollars. ${ }^{8}$

At West Virginia University School of Medicine, where Dr Cucuzzella is a practising family physician and professor, outpatient and inpatient clinics are overwhelmed every day with cases of diabetes and metabolic syndrome. As of 2016,37.7\% of adults in West Virginia are obese. By best estimates, 15\% have type 2 diabetes (T2D), and perhaps more than $50 \%$ have pre-diabetes. ${ }^{9,10}$ Most of these patients are completely unaware of their condition and the impacts of a poor diet, as are many of these patients' health care providers. These patients lack the tools and support to halt or reverse their disease.

This report describes a simple approach to reversing T2D and pre-diabetes (remission is defined as normoglycaemia for 1 year without active pharmacotherapy, with the disease 'cured' after 5 years $)^{11}$ that is showing promise in the fight against this deadly and costly disease. It is based on

Copyright: () 2017. The Authors. Licensee: AOSIS. This work is licensed under the Creative Commons Attribution License. 
survey findings from more than 1500 people from West Virginia, other parts of the United States and the world who have benefited from a low-carbohydrate diet.

\section{Metabolic syndrome as pre-diabetes}

Metabolic syndrome, or 'Syndrome X', was first identified by endocrinologist Gerald Reaven in the 1980s, and the root cause of this condition is described as 'insulin resistance'. ${ }^{12}$ Dr Stephen Phinney and Dr Jeff Volek explain this further as a condition of 'carbohydrate intolerance'. ${ }^{13}$ According to recent NHANES data, almost one in three Americans now have metabolic syndrome. ${ }^{14}$ Metabolic syndrome is a sign of poor carbohydrate metabolism and hyperinsulinaemia and, if not reversed, portends an inevitable decline in overall health. ${ }^{15}$ Markers of metabolic syndrome are abdominal obesity, high blood glucose, high triglycerides (TG), low high-density lipoprotein (HDL) cholesterol and high blood pressure. Other associated conditions are increased inflammation, vascular dysfunction, non-alcoholic fatty liver disease (NAFLD), polycystic ovary syndrome, sleep apnea and some types of cancer and dementia. ${ }^{16,17,18,19,20,21,22,23,24}$ Obesity is commonly viewed as the cause of metabolic syndrome. However, while obesity is highly correlated with the condition, we (and others) suggest that it is the expansion of adipose stores beyond a person's individual storage capacity, ${ }^{25,26}$ driven by and in conjunction with hyperinsulinaemia because of the overconsumption of processed dietary carbohydrates in the setting of a Western diet - so prevalent in modern society - that drives this disease process. ${ }^{26,27,28}$ Inflammation, especially the presence of pro-inflammatory macrophages in fat stores, such as the visceral adipose tissue, is another key marker of the developing pathology..$^{25,29}$ The inflamed adipose tissue appears to lose its ability to properly respond to insulin, resulting in loss of its capacity to protectively buffer fatty acids (including sugars and starches converted to fatty acids via de novo lipogenesis to be 'safely' stored). ${ }^{25,29}$ This leads to reduced capacity to clear circulating glucose, as well as greater hepatic exposure to gluconeogenic precursors from rapid fatty acid turnover occurring in the insulin-resistant adipose tissue, ${ }^{30}$ both resulting in the persistently elevated blood glucose associated with metabolic syndrome. ${ }^{31}$ As a population-level intervention, restriction of carbohydrates, a key contributor to the development of metabolic syndrome (especially when processed), should therefore be considered a primary intervention for those with metabolic disease.

\section{Type $\mathbf{2}$ diabetes reversal: Is it possible?}

The prospect of reversing progressive T2D is somewhat new to both the public and health care practitioners. Many assume the diagnosis is a purely progressive disease, ${ }^{32,33}$ including an inevitable march towards worsening health and organ systems failure. ${ }^{34}$ In the lexicon of diabetes care, 'intensive management' has superseded 'cure', 'remission' or 'reversal'. The ADA's 2017 Standards of Medical Care in Diabetes states that: 'Diabetes is a complex, chronic illness requiring continuous medical care with multifactorial risk-reduction strategies beyond glycaemic control' ${ }^{35}$ In line with this, the ADA's 2013 Nutrition Therapy Recommendations for the Management of Adults with Diabetes states that T2D is 'progressive' in nature and 'nutrition and physical activity interventions alone (i.e. without pharmacotherapy) are generally not adequately effective in maintaining persistent glycaemic control over time for many individuals' ${ }^{36}$

In current treatment approaches, pharmacotherapy typically is the focal point and carbohydrate restriction is deemphasised. For instance, a recent Kaiser Permanente study involving 120000 patients concluded that prolonged T2D remission in community settings without bariatric surgery is very rare; it occurred in only $0.007 \%$ of the study population. During the 7-year study, more study participants (1.7\%) died than the percentage who experienced any level of remission, and diabetes-associated medication use, health care costs and complications increased. ${ }^{37}$ In addition, seven multinational, multicentre, randomised controlled trials aimed at achieving tight blood glucose control with medications failed to demonstrate the expected reductions in heart disease, the major killer of patients with diabetes, or in overall mortality. ${ }^{38,39,40,41,42,43,44}$ In contrast to these outcomes, strong evidence exists for a promising alternative approach.

\section{Trials of low-carbohydrate diets: Significant findings for a new approach to type $\mathbf{2}$ diabetes}

The first well-recorded version of a low-carbohydrate diet was described in 1863 by the Englishman William Banting, who restricted starchy and sugary foods to overcome obesity on the advice of his physician. ${ }^{45}$ The popularity of the diet as an effective weight loss regimen continued well into the 20th century, when it was common knowledge that 'sugar and starches are fattening'. By mid-20th century, studies on the low-carbohydrate diet were a rarity in the medical and nutritional literature because of a growing belief that fat, and particularly saturated fat, not carbohydrate, was the more likely dietary culprit. ${ }^{46}$ Although resistance within the medical community persists, ${ }^{47}$ in recent years dietary fat has slowly been exonerated, in accordance with the best available evidence. ${ }^{48,49,50,51,52,53}$ Studies are also now emerging to show the efficacy, sustainability and other positive effects of lowcarbohydrate diets, especially in those with metabolic disease. ${ }^{54,55,56,57,58,59,60,61}$

The definition of a low-carbohydrate diet varies in the literature, but most in the field agree that anything over $130 \mathrm{~g}-150 \mathrm{~g}$ per day is not low carbohydrate. ${ }^{62}$ An amount of less than $50 \mathrm{~g}$ of carbohydrate per day is considered very low carbohydrate, which would put most adults into nutritional ketosis. ${ }^{63}$ During this state, the body relies primarily on fatty acids and ketone bodies produced from fat stores, not glucose, for energy.

Numerous randomised, controlled trials have shown that well-formulated low-carbohydrate dietary patterns are highly effective for treating obesity and improving a spectrum of risk 
factors typical of patients with metabolic syndrome and diabetes who previously ate a traditional diet. $2,64,65,66,67,68,69,70,71$ An example is a report by McKenzie et al. on the interim results of their 2-year outpatient trial on T2D patients adhering to a ketogenic diet (very low carbohydrate, usually $<50 \mathrm{~g} /$ day). ${ }^{13}$ Although not a randomised, controlled trial, the trial demonstrates the wide-scale applicability and efficacy of carbohydrate restriction. At 10 weeks, $91 \%$ of the 262 patients remained active in the trial and had experienced an average $\mathrm{HbA} 1 \mathrm{c}$ reduction from $7.6 \%$ to $6.5 \%$ and an average of $7.2 \%$ body weight loss. More than half of the participants (56.8\%) had reduced or eliminated one or more diabetes medications. At 6 months, $89 \%$ of the participants were retained, and weight loss averaged $12 \%$. These findings are congruent with the physiology of insulin accelerating intracellular storage of glucose and fats, whereas reduced serum insulin from a lowcarbohydrate approach allows lipolysis and gives the body access to its stored fat as an energy source. ${ }^{72}$ In contrast, intensive management of T2D with the ADA-recommended low-fat diet and standard drug regimen routinely results in minimal weight loss even when glucose control is optimised..$^{38}$

In a critical review of the literature, Feinman et al. present 12 points of evidence (summarised below) to support the low-carbohydrate diet as the best first-line strategy for treating T2D and the most effective adjunct to pharmacology in type 1 diabetes (T1D) ${ }^{55}$ :

1. Dietary carbohydrate restriction has the greatest effect on decreasing abnormally high blood glucose levels, the most salient feature of diabetes.

2. Increased caloric intake, the driver of the obesity and T2D epidemics, has been due almost entirely to increased carbohydrate consumption.

3. Weight loss is not required to reap the benefits of a lowcarbohydrate diet, which include reversal of T2D.

4. For weight loss, no other dietary intervention has proven to be better than carbohydrate restriction.

5. For people with $\mathrm{T} 2 \mathrm{D}$, the low-carbohydrate diet is as effective as other dietary interventions and often significantly better.

6. Replacement of carbohydrate with protein generally improves glycaemic control.

7. Total fat and saturated fat intake do not correlate with risk of cardiovascular disease.

8. Plasma-saturated fatty acid levels are affected more by eating carbohydrates than eating fats.

9. The best predictor of microvascular, and to a lesser extent macrovascular, complications in patients with T2D is glycaemic control (as measured by $\mathrm{HbA1c}$ ).

10. Dietary carbohydrate restriction is the most effective method (other than starvation) for reducing serum TG and increasing high-density lipoproteins.

11. Low-carbohydrate diets reduce and frequently eliminate medications for T2D patients and usually result in lower insulin doses for patients with T1D.

12. Intensive glucose lowering by carbohydrate restriction has none of the side effects associated with intensive pharmacologic therapies.
Despitea growing body of evidencefor low-carbohydratediets' superior results in the management of obesity, cardiovascular disease risk, metabolic syndrome and T2D, objections by the medical and public health communities persist. ${ }^{73}$ This is frequently based on flawed or outdated evidence. ${ }^{74}$ For example, misunderstanding about the body's need for glucose, in particular by the central nervous system, continues despite basic scientific knowledge to the contrary. ${ }^{5}$ In concert, the ADA does not recommend a low-carbohydrate diet for diabetes management. While recognising that 'carbohydrate intake has a direct effect on postprandial glucose levels' and 'total amount of carbohydrate eaten is the primary predictor of glycaemic response', the ADA advises that 'a variety of eating patterns (combinations of different foods or food groups) are acceptable for the management of diabetes' and recommends adjusting carbohydrate intake to mealtime insulin dosing. ${ }^{36}$ The ADA has refrained from making a robust recommendation for carbohydrate restriction. It posits that 'evidence is inconclusive for an ideal amount of carbohydrate intake for people with diabetes' ${ }^{36}$

\section{Aim and objectives}

Although a reduced-carbohydrate approach may theoretically improve health, if it is too difficult to follow long term or if it brings with it unwanted effects, the idea that people should reduce their carbohydrates is at best irrelevant. Our hypothesis is that if one adheres to a well-formulated low-carbohydrate diet, the success and health benefits can be maintained over years and even for a lifetime. To probe the real-life utility of such an approach, previous examinations of people following some kind of carbohydrate restriction have been conducted. For example, Tim Noakes, a South African physician and low-carbohydrate diet researcher, published an analysis of more than 100 communications he had received from people following some kind of carbohydrate restriction. The participants reported reduced weight, hunger, irritable bowel syndrome symptoms, hypertension and medication needs, as well as improved glycaemic control and exercise capacity. ${ }^{75} \mathrm{~A}$ survey of more than 2000 members of an online, lowcarbohydrate support group found positive health outcomes for participants, such as decreased body weight and an improved lipid profile. ${ }^{76}$ A survey of more than 2500 people following a low-carbohydrate diet of some type (or a paleo diet, which is often a reduced-carbohydrate diet) found a variety of positive health benefits such as reduced weight, hunger, irritable bowel syndrome symptoms, joint pain, arthritis pain, brain fog and acne, as well as improved glycaemic control, psychological well-being, athletic performance and energy. ${ }^{77}$ About 100 people from the National Weight Control Registry, which tracks people who have long-term weight loss success, reported using a low-carbohydrate diet approach and reported long-term weight loss with reduced hunger. ${ }^{78}$

The purpose of this research was to gain a detailed, updated understanding of adults who were already voluntarily following a low-carbohydrate diet. Because long-term dietary trials are complex and costly, we were especially interested in the experience of long-term diet adherents. Such research is 
hypothesis-generating and enables researchers to explore the actual lived experience of people following such a dietary approach.

\section{Methods \\ Study design}

The Low Carb Lifestyle Survey was a quality improvement project for the American Board of Family Physicians (ABFM), developed by Dr Mark Cucuzzella and with survey design assistance from collaborators in the United Kingdom (diabetes.co.uk)

\section{Setting, study population and sampling strategy}

The survey was shared with the American and international 'low-carb' community via social media and through international health care professionals who support therapeutic uses of low-carbohydrate diets. As Dr Cucuzzella has been recommending a low-carbohydrate diet as an option to his patients with T2D for 6 years, the survey was also shared with individual patients he sees and members of his local community.

\section{Data collection}

The 57-question survey was administered on Survey Monkey (an online survey company); the survey was open from December 2016 to June 2017. The survey included closed-ended, multiple-choice and open-ended questions. Responses to the survey were kept confidential. The full 57-question survey can be viewed in supplemental materials (see Appendix 1).

\section{Data analysis}

Where appropriate, we used chi-squared tests to compare proportions and paired $t$-tests to compare means and standard deviation changes within the same groups. Statistical analyses were performed using IBM SPSS software Version 22 (SPSS Inc., Chicago, IL) and GraphPad Prism version 7 (GraphPad Software, La Jolla, CA).

\section{Ethical considerations}

The American Board of Family Medicine (ABFM) peerreviewed and approved the project before release. After results were collected, the ABFM again reviewed the project and determined that it met standards for a Quality Improvement (QI) project. A QI project relevant to the quality and standards of the ABFM is mandatory for maintenance of certification as a Board Certified Family Physician.

\section{Results}

\section{Survey respondent characteristics}

The survey was completed by 1580 respondents. Respondents were required to answer all questions, with the exception of the open-ended items. The majority of respondents resided in the United States, with the rest residing elsewhere (Table 1).
TABLE 1: Survey respondent characteristics.

\begin{tabular}{|c|c|}
\hline Characteristic & $N(\%)$ \\
\hline \multicolumn{2}{|l|}{ Gender } \\
\hline Female & $982(62.2)$ \\
\hline Male & $598(37.9)$ \\
\hline \multicolumn{2}{|l|}{ Age } \\
\hline$<20$ & $2(0.1)$ \\
\hline $20-29$ & $34(2.2)$ \\
\hline $30-39$ & $223(14.1)$ \\
\hline $40-49$ & $483(30.6)$ \\
\hline $50-59$ & $524(33.2)$ \\
\hline $60-69$ & 266 (16.9) \\
\hline$>70$ & $48(3.0)$ \\
\hline \multicolumn{2}{|l|}{ Race/ethnicity } \\
\hline American Indian or Alaskan Native & $12(0.8)$ \\
\hline Asian or Pacific Islander & $36(2.3)$ \\
\hline Black or African American & $25(1.6)$ \\
\hline Hispanic or Latino & $58(3.7)$ \\
\hline White/Caucasian & $1435(90.1)$ \\
\hline Prefer not to answer & $10(0.6)$ \\
\hline Other & $44(2.8)$ \\
\hline \multicolumn{2}{|l|}{ Place of residence } \\
\hline USA & $919(58.2)$ \\
\hline Canada & $128(8.1)$ \\
\hline South and Central America & $15(0.9)$ \\
\hline Europe & $289(18.3)$ \\
\hline South Africa & $43(2.7)$ \\
\hline Middle East & $16(1.0)$ \\
\hline Asia and India & $18(1.1)$ \\
\hline Australia and New Zealand & $152(9.6)$ \\
\hline \multicolumn{2}{|l|}{ Occupational status } \\
\hline Full-time employment & $994(63.0)$ \\
\hline Part-time employment & $171(11.0)$ \\
\hline Currently not working & $146(9.2)$ \\
\hline Retired & $238(15.1)$ \\
\hline Student & $31(2.0)$ \\
\hline \multicolumn{2}{|l|}{ How learned about low-carbohydrate diet } \\
\hline Internet & $616(39.0)$ \\
\hline Medical professional & $168(10.6)$ \\
\hline Family member or friend & $315(19.9)$ \\
\hline Book & $240(15.2)$ \\
\hline Community group & $22(1.4)$ \\
\hline Other & $10(13.2)$ \\
\hline \multicolumn{2}{|l|}{ Reason for starting low-carbohydrate diet } \\
\hline To improve chronic health condition & $696(44.1)$ \\
\hline For weight loss & $1184(75.0)$ \\
\hline To enhance athletic performance & $211(13.4)$ \\
\hline To have more energy throughout day & $498(31.5)$ \\
\hline Friend or family member on low-carbohydrate diet & $89(5.6)$ \\
\hline No specific reason - just curious & $37(2.3)$ \\
\hline Other & $334(21.1)$ \\
\hline \multicolumn{2}{|l|}{ Length of time on low-carbohydrate diet } \\
\hline$<1$ month & $34(2.2)$ \\
\hline $1-3$ months & $185(11.8)$ \\
\hline $3-6$ months & $180(11.4)$ \\
\hline 6 months -1 year & $298(18.9)$ \\
\hline $1-2$ years & $347(22.0)$ \\
\hline$>2$ years & $536(34.0)$ \\
\hline \multicolumn{2}{|l|}{ Amount of carbohydrates consumed daily } \\
\hline$<30 \mathrm{~g}$ & $780(49.4)$ \\
\hline $30 \mathrm{~g}-50 \mathrm{~g}$ & $502(31.8)$ \\
\hline $50 \mathrm{~g}-100 \mathrm{~g}$ & $252(16.0)$ \\
\hline $100 \mathrm{~g}-200 \mathrm{~g}$ & $42(2.7)$ \\
\hline $200 \mathrm{~g}-300 \mathrm{~g}$ & $4(0.3)$ \\
\hline \multicolumn{2}{|l|}{ Physical activity } \\
\hline Minutes per week - Min (SD) & $164(192)$ \\
\hline
\end{tabular}


Most of the respondents were female, white, middle-aged and working full time. Of the survey respondents, 97\% said that they considered themselves to be adherent to a lowcarbohydrate diet. More than half of the respondents said that they had been on a low-carbohydrate diet for at least 1 year. The most commonly reported way respondents had learned about the low-carbohydrate diet was through the Internet. Respondents were allowed to choose more than one reason for starting a low-carbohydrate diet. Three out of four respondents said they started the diet for weight loss, but chronic disease improvement and a desire for more energy were also common responses.

Almost half (49\%) of the respondents reported a very restricted average carbohydrate intake of less than $30 \mathrm{~g}$ per day. Almost one-third (32\%) reported an average carbohydrate intake of $30 \mathrm{~g}-50 \mathrm{~g}$ per day, $16 \%$ reported $50 \mathrm{~g}-100 \mathrm{~g}$ per day and the remaining 3\% reported more than 100 g per day. Average carbohydrate intake was inversely associated with amount of time spent on the diet; that is, of those adherents for less than 6 months, $65 \%$ reported an average daily carbohydrate intake of less than $30 \mathrm{~g}$. For participants adherent from 6 months to 2 years, daily consumption of less than $30 \mathrm{~g}$ daily still comprised the majority response, but had declined with time. By 2 years, those consuming less than $30 \mathrm{~g}$ daily and those consuming $30 \mathrm{~g}-50 \mathrm{~g}$ daily were even at $38 \%$ each. This is consistent with one approach to carbohydrate restriction, starting with a very low-carbohydrate intake and then gradually increasing the carbohydrate level as time goes on. ${ }^{79}$ The amount of weekly physical activity reported was an average of $164 \mathrm{~min}$, with $18 \%$ reporting no regular physical activity.

\section{Weight loss and lab test values}

The large majority of respondents reported weight loss and waist circumference reduction with a low-carbohydrate diet (Table 2). Three out of four reported weight loss of 10 pounds or more, with more than one-third of respondents reporting a weight loss of more than 30 pounds. Similarly, $81 \%$ respondents reported some reduction in waist size, with $17 \%$ reporting a reduction of 5 inches or more. Decreases in weight

\begin{tabular}{lc} 
TABLE 2: Weight and waist circumference change with low-carbohydrate diet. \\
\hline Type of Change & $\boldsymbol{N}(\%)$ \\
\hline Change in weight & $32(2.0)$ \\
Did not weigh & $74(4.7)$ \\
Weight stayed within 2 pounds of starting weight & $46(2.9)$ \\
Gained 2 or more pounds & $254(16.1)$ \\
Lost 2-10 pounds & $555(35.1)$ \\
Lost 10-30 pounds & $346(21.9)$ \\
Lost 30-50 pounds & $273(17.3)$ \\
Lost > 50 pounds & \\
Change in waist circumference & $280(17.7)$ \\
Did not measure & $18(1.1)$ \\
Gained waist circumference & $111(7.0)$ \\
Lost $<1$ inch & $512(32.4)$ \\
Lost 1-3 inches & $387(24.5)$ \\
Lost 3-5 inches & $272(17.2)$ \\
Lost $>5$ inches &
\end{tabular}

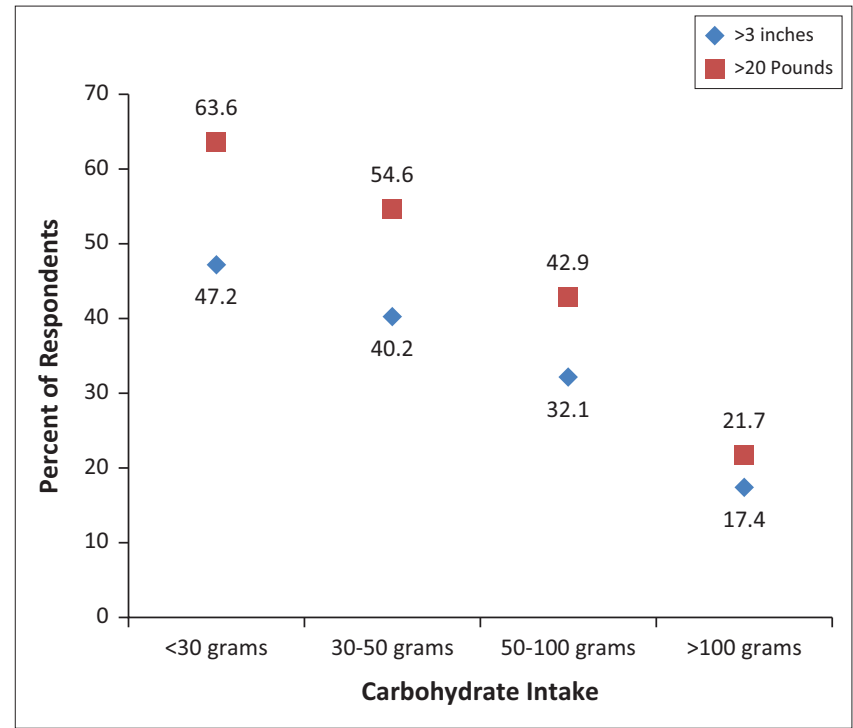

FIGURE 1: Weight and waist circumference loss in relation to carbohydrate intake.

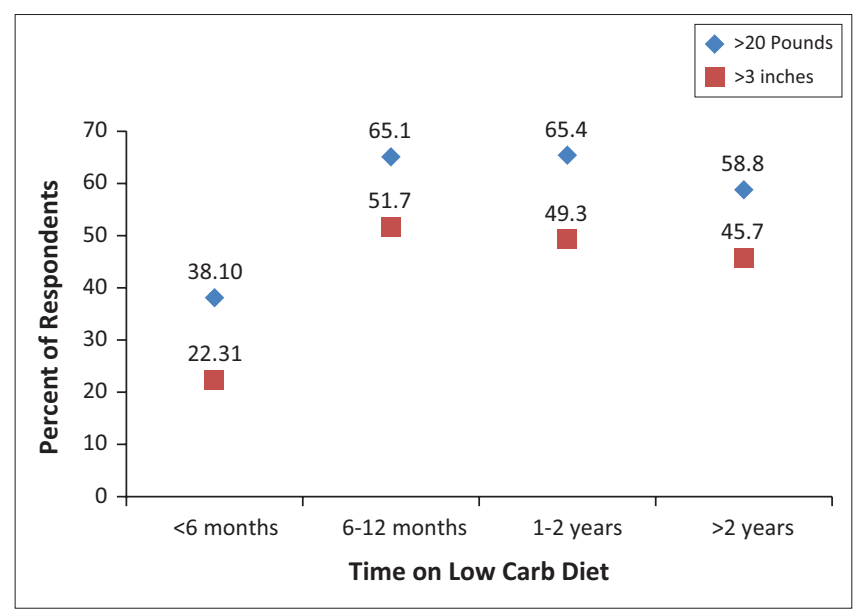

FIGURE 2: Weight and waist circumference loss in relation to time on a lowcarbohydrate diet.

and waist circumference correlated inversely with daily carbohydrate intake, with a greater proportion of participants (those consuming less than $30 \mathrm{~g}$ of carbohydrate per day) reporting more than 3 inches lost from the waist or more than 20 pounds total weight loss (Figure 1).

\section{Long-term weight loss and waist circumference reduction}

Among respondents who knew their weight and waist circumference before and after diet initiation, at 6-12 months on the diet (Figure 2), 65\% reported a weight loss of 20 pounds or more and 52\% reported a waist circumference reduction of 3 inches or more. We found similar results for people who reported following a reduced carbohydrate diet for even longer. For example, for those on the diet 2 years or more, $59 \%$ reported a weight loss of 20 pounds or more and $46 \%$ reported a waist circumference reduction of 3 inches or more. Providing laboratory values was optional in the survey. Lab test values of respondents who knew their values before diet initiation and after are shown in Tables 3 and 4. Improvements were reported for fasting blood 
TABLE 3: Lab test values before and after low-carbohydrate diet initiation.

\begin{tabular}{|c|c|c|c|c|c|}
\hline Lab test values & $N$ & Before, mean (SD) & After, mean (SD) & Difference, mean (SD) & $p$ \\
\hline Fasting blood glucose & 352 & 143 mg/dL (58.2) & 99 mg/dL (72.5) & $44.4(66.2)$ & $<0.001$ \\
\hline Postprandial blood glucose & 267 & 175 mg/dL (45.8) & 107 mg/dL (22.9) & $69.3(67.6)$ & $<0.001$ \\
\hline Total cholesterol & 221 & 210 mg/dL (47.5) & 232 mg/dL (59.9) & $21.9(62.2)$ & $<0.001$ \\
\hline LDL cholesterol & 221 & 127 mg/dL (44.0) & 144 mg/dL (55.6) & $16.9(53.9)$ & $<0.001$ \\
\hline HDL cholesterol & 221 & 57 mg/dL (21.1) & 71 mg/dL (24.4) & $14.6(17.7)$ & $<0.001$ \\
\hline Triglycerides & 221 & 149 mg/dL (144.3) & 82 mg/dL (55.3) & $-67.7(144.0)$ & $<0.001$ \\
\hline Triglyceride/HDL ratio & 221 & $3.49(4.62)$ & $1.37(1.21)$ & $-2.11(4.44)$ & $<0.001$ \\
\hline
\end{tabular}

Note: Statistical results determined by paired $t$-tests. This includes only participants with before and after values.

SD, Standard deviation; LDL, low-density lipoprotein; HDL, high-density lipoprotein.

TABLE 4: Proportion of participants with HbA1c levels in the normal, prediabetes or type 2 diabetes ranges before and after initiation of a lowcarbohydrate diet $(N=495)$.

\begin{tabular}{lccc}
\hline HbA1c & Before, $\boldsymbol{N}(\%)$ & After, $\boldsymbol{N}(\%)$ & $p$ \\
\hline$<5.5$ (Normal) & $82(16.6)$ & $241(65.3)$ & $<0.001$ \\
$5.5-6.4$ (Pre-diabetes) & $173(34.9)$ & $137(27.7)$ & $<0.001$ \\
$>6.5$ (Type 2 diabetes) & $240(48.5)$ & $35(7.1)$ & $<0.001$ \\
\hline
\end{tabular}

Note: Statistical results determined by chi-squared tests for proportion of people in each category. This includes only participants with before and after values.

TABLE 5: HbA1c values stratified by carbohydrate intake.

\begin{tabular}{lccc}
\hline $\begin{array}{l}\text { HbA1c value per } \\
\text { carbohydrate intake } \\
\text { level }\end{array}$ & $\begin{array}{c}\text { Before initiation } \\
\boldsymbol{N}(\%)\end{array}$ & $\begin{array}{c}\text { After initiation } \\
\boldsymbol{N}(\%)\end{array}$ & $\begin{array}{c}\text { Chi-square statistic } \\
(\boldsymbol{p})\end{array}$ \\
\hline$<\mathbf{3 0} \mathrm{g}$ & $139(53.9)$ & $16(6.2)$ & $203.5(<0.0001)$ \\
6.5 or more & $88(34.1)$ & $65(25.2)$ & \\
$5.5-6.4$ & $31(12.0)$ & $177(68.6)$ & \\
Under 5.5 & & & \\
$\mathbf{3 0}$ g-50 g & $69(45.1)$ & $14(9.2)$ & $71.8(<0.0001)$ \\
6.5 or more & $55(35.9)$ & $45(29.4)$ & \\
$5.5-6.4$ & $29(19.0)$ & $94(61.4)$ & \\
Under 5.5 & & & \\
$\mathbf{5 0}$ g-100 g & $28(36.8)$ & $4(5.3)$ & \\
6.5 or more & $28(36.8)$ & $23(30.3)$ & \\
$5.5-6.4$ & $20(26.3)$ & $49(64.5)$ & \\
Under 5.5 & & & \\
$>\mathbf{1 0 0} \mathrm{g}$ & $4(50.0)$ & $1(12.5)$ & \\
6.5 or more & $2(25.0)$ & $4(50.0)$ & \\
$5.5-6.4$ & $2(25.0)$ & $3(37.5)$ & \\
Under 5.5 & & & \\
\hline
\end{tabular}

Note: Calculated using a $3 \times 2$ contingency table and chi-squared test.

glucose, postprandial blood glucose and triglyceride/HDL (TG/HDL) ratio (Table 3 ).

\section{Glycaemic control}

We also examined the proportion of participants reporting $\mathrm{HbA1c}$ levels in the normal range or in the ranges diagnostic of pre-diabetes or T2D (Table 4). We noticed large improvements. For example, the proportion of participants reporting an $\mathrm{HbA1c}$ below 5.5 increased almost fourfold $(17 \%$ to $65 \%)$. Almost half $(49 \%)$ reported an $\mathrm{HbA} 1 \mathrm{c}$ of 6.5 or more before diet initiation. After initiation, fewer than one in $10(7 \%)$ reported an $\mathrm{HbA1c}$ that high. Absolute increase in participants reporting a normal $\mathrm{HbA1c}(<5.5$; $48.7 \%$ increase) and absolute decrease in participants reporting a diabetic $\mathrm{HbA1c}(\geq 6.5 ; 41.4 \%)$ were both greatest in the group eating less than $30 \mathrm{~g}$ of carbohydrate per day, with smaller absolute improvements with increasing carbohydrate intake (Table 5).

\section{Medication use}

Respondents reported declines in use of medications (e.g., antidepressant, anti-anxiety, sleep aids, pain relief, antiinflammatory and phosphodiesterase type 5 inhibitors for erectile dysfunction) after starting the diet (Table 6). The use of all types of medications (except for erectile dysfunction) reduced by more than $50 \%$.

Small minorities of respondents reported current use of medications for diabetes, high blood pressure and hyperlipidaemia, with some reporting having reduced or completely discontinued such medications after initiating the diet (Table 7). While more than half of the respondents said that medication costs were not relevant for them, (e.g. NHS on no medication costs or not on medication) $25 \%$ reported a savings, with the average reported savings in medications cost being $\$ 288$ per month.

\section{Energy, mobility, pain, physical and emotional well-being, and between-meal state}

Respondents reported improvements in energy level (see Figure 3), ability to perform usual activities (such as housework or leisure activities), pain and emotional health after starting a low-carbohydrate diet (Table 8). For example, before initiation, $59 \%$ of respondents reported low energy levels and only $4 \%$ reported high energy levels, compared to $3 \%$ and $51 \%$, respectively, after initiation. The numbers of respondents reporting moderate to extreme problems with mobility, pain or symptoms of anxiety or depression declined after diet initiation (Table 8). Respondents reported improvement in a variety of aspects of physical and psychological well-being after starting a low-carbohydrate diet. For example, at least eight out of 10 respondents reported improvement in outlook, happiness and self-esteem, and six out of 10 reported improved confidence in controlling blood sugar (Table 9). Similarly, before initiating a low-carbohydrate diet, the great majority of respondents reported negative between-meal experiences, such as intense hunger, tiredness and difficulty concentrating (Table 10). Fewer than one in five respondents reported having such experiences after diet initiation.

\section{Other health changes, challenges and knowledge gained}

Respondents were invited to answer three open-ended questions about their experiences on a low-carbohydrate 
TABLE 6: Medication use before and after low-carbohydrate diet initiation.

\begin{tabular}{lccc}
\hline Medication type & Used before, $\boldsymbol{N}(\%)$ & Used after, $\boldsymbol{N}(\%)$ & $\boldsymbol{p}$ \\
\hline Antidepressant & $195(12.5)$ & $90(5.8)$ & $<0.001$ \\
Anti-anxiety & $112(7.3)$ & $52(3.4)$ & $<0.001$ \\
Sleep aids & $176(11.4)$ & $74(4.8)$ & $<.001$ \\
Painkillers & $342(22.1)$ & $77(5.0)$ & $<0.001$ \\
Anti-inflammatory & $417(27.1)$ & $101(6.8)$ & $<0.001$ \\
Erectile dysfunction & $17(1.1)$ & $13(0.86)$ & 0.46 \\
\hline
\end{tabular}

Note: Statistical results determined by chi-squared tests.

TABLE 7: Medication use.

\begin{tabular}{lcc}
\hline Medication type & Currently use, $\boldsymbol{N}(\%)$ & $\begin{array}{c}\text { Reduced or stopped since } \\
\text { diet initiation, } \boldsymbol{N}(\%)\end{array}$ \\
\hline Diabetes & $140(8.9)$ & $107(6.8)$ \\
Blood pressure & $221(14.0)$ & $178(11.3)$ \\
Cholesterol & $82(5.2)$ & $93(5.9)$ \\
\hline
\end{tabular}

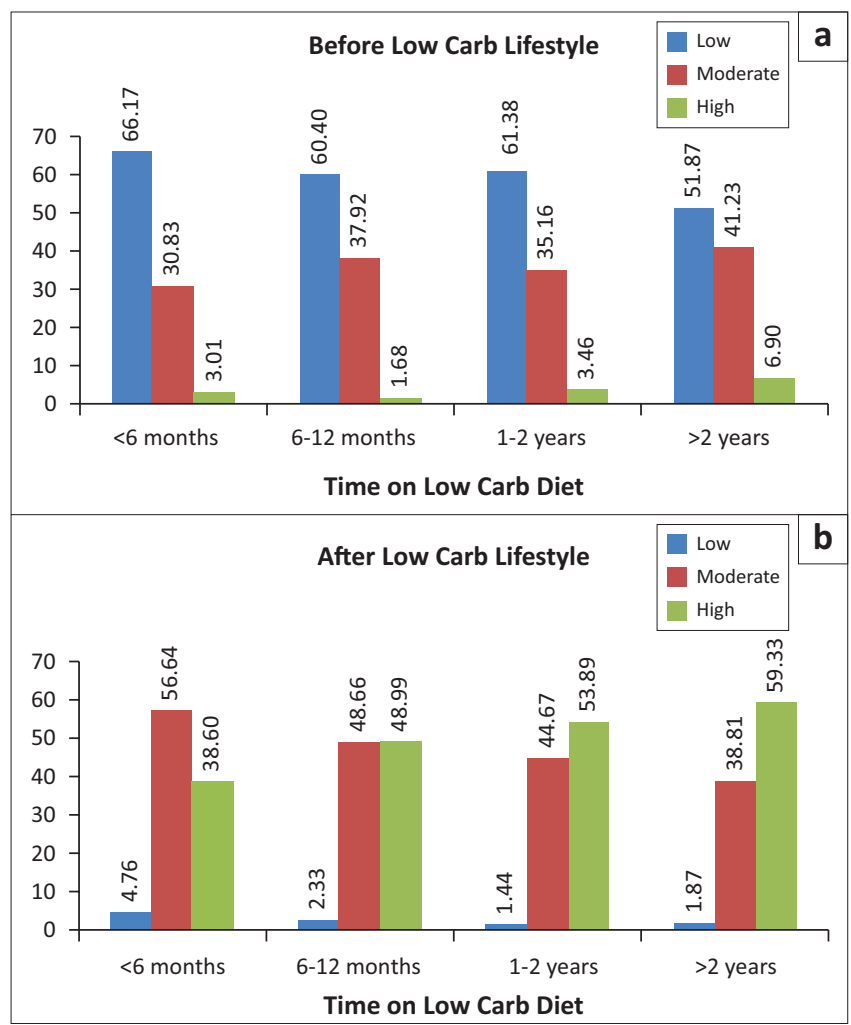

FIGURE 3: Energy level before and after a low-carb diet broken down by amount of time following a low-carb lifestyle.

diet. Common responses are summarised in Table 11. Commonly reported health changes were improvements on a wide spectrum: breathing and allergies, markers of NAFLD, libido and reproductive health, mental clarity and digestion. Commonly reported challenges related to a low-carbohydrate diet included negative reactions from family, friends and health professionals; dining out, special occasions and travelling; flu-like symptoms associated with transitioning to a low-carbohydrate diet; and desires for certain foods. Common reports of the important learning or information gained from being on a low-carbohydrate diet pertained to insulin resistance and metabolic syndrome; the difference between nutritional ketosis and ketoacidosis; and awareness about how different foods affect satiety, weight gain and how one feels.
TABLE 8: Energy and activity, physical and emotional well-being before and after low-carbohydrate diet initiation.

\begin{tabular}{|c|c|c|c|}
\hline Indicator & Before $N(\%)$ & After $N(\%)$ & $p$ \\
\hline \multicolumn{4}{|l|}{ Energy level } \\
\hline Low & $935(59.2)$ & $41(2.6)$ & $<0.001$ \\
\hline Moderate & $579(36.7)$ & $734(46.5)$ & $<0.001$ \\
\hline High & $66(4.2)$ & $805(51.0)$ & $<0.001$ \\
\hline \multicolumn{4}{|l|}{ Usual activities } \\
\hline Slight or no problem & $1224(77.5)$ & $1535(97.2)$ & $<0.001$ \\
\hline Moderate or severe problem & $347(22.0)$ & $43(2.7)$ & $<0.001$ \\
\hline Unable to perform & $0(0.6)$ & $2(0.1)$ & $>0.15$ \\
\hline \multicolumn{4}{|l|}{ Mobility } \\
\hline Slight or no problem & $1302(82.4)$ & $1531(96.9)$ & $<0.001$ \\
\hline Moderate or severe problem & $272(17.2)$ & $47(3.0)$ & $<0.001$ \\
\hline Unable to walk & $6(0.4)$ & $2(0.1)$ & $>0.15$ \\
\hline \multicolumn{4}{|l|}{ Pain or discomfort } \\
\hline Slight or no pain or discomfort & $906(57.3)$ & $1502(95.1)$ & $<0.001$ \\
\hline Moderate or severe & $650(41.1)$ & 78 (4.9) & $<0.001$ \\
\hline Extreme pain & $24(1.5)$ & $0(0)$ & $<0.001$ \\
\hline \multicolumn{4}{|l|}{ Emotional health } \\
\hline Slight or no anxiety or depression & $1053(66.7)$ & $1519(96.1)$ & $<0.001$ \\
\hline $\begin{array}{l}\text { Moderate or severe anxiety or } \\
\text { depression }\end{array}$ & $485(30.7)$ & $60(3.8)$ & $<0.001$ \\
\hline Extreme anxiety or depression & $42(2.7)$ & $1(0.1)$ & $<0.001$ \\
\hline
\end{tabular}

Note: Statistical results determined by chi-squared tests for proportion of people in each category.

TABLE 9: Changes in physical and psychological well-being after starting low-carbohydrate diet.

\begin{tabular}{lccc}
\hline Indicator & Improved, $\boldsymbol{N}(\%)$ & No change, $\boldsymbol{N}(\%)$ & Worsened, $\boldsymbol{N}(\%)$ \\
\hline $\begin{array}{l}\text { General quality of } \\
\text { life }\end{array}$ & $1461(92.5)$ & $105(6.7)$ & $14(0.9)$ \\
$\begin{array}{l}\text { Quality of sleep } \\
\begin{array}{l}\text { Confidence in } \\
\text { controlling blood } \\
\text { sugar }\end{array}\end{array}$ & $1094(69.2)$ & $433(27.4)$ & $53(3.4)$ \\
$\begin{array}{l}\text { Motivation to } \\
\text { maintain changes } \\
\text { made in lifestyle }\end{array}$ & $1019(64.5)$ & $551(34.9)$ & $10(0.6)$ \\
$\begin{array}{l}\text { Confidence in food } \\
\text { choices }\end{array}$ & $1509(95.5)$ & $57(5.5)$ & $11(0.7)$ \\
$\begin{array}{l}\text { Outlook on life } \\
\begin{array}{l}\text { Self-esteem } \\
\text { Happiness }\end{array}\end{array}$ & $1385(87.7)$ & $184(11.7)$ & $11(0.7)$ \\
\hline
\end{tabular}

TABLE 10: Between-meal experiences.

\begin{tabular}{lccc}
\hline Indicator & $\begin{array}{c}\text { Experienced before, Experienced after, } \boldsymbol{N} \\
\boldsymbol{N}(\%)\end{array}$ & $\boldsymbol{p}$ \\
\hline Intense hunger & $1375(87.1)$ & $55(3.5)$ & $<0.001$ \\
Tiredness & $1480(93.9)$ & $305(19.3)$ & $<0.001$ \\
$\begin{array}{l}\text { Difficulty } \\
\text { concentrating }\end{array}$ & $1300(83.0)$ & $177(11.3)$ & $<0.001$ \\
Mood swings & $1160(74.3)$ & $154(9.8)$ & $<0.001$ \\
Irritability & $1251(79.9)$ & $255(16.3)$ & $<0.001$ \\
Anxiety & $925(59.4)$ & $207(13.3)$ & $<0.001$ \\
\hline
\end{tabular}

Note: Statistical results determined by chi-squared tests.

\section{Discussion}

To date, few studies have been published on the efficacy of low-carbohydrate diets for weight loss or reversal of metabolic syndrome and T2D beyond 2 years in duration. ${ }^{80}$ Our survey offers a unique perspective on this issue. It garnered a large, international cohort of individuals, with more than 500 of them being adherent to a low-carbohydrate diet for more than 2 years. Because respondents were overwhelmingly people succeeding on the diet, the data give 
TABLE 11: Commonly reported free-response answers.

\begin{tabular}{|c|c|c|}
\hline $\begin{array}{l}\text { Have there been any } \\
\text { other changes to your } \\
\text { health that we have not } \\
\text { already covered? } \\
\text { ( } 838 \text { responses) }\end{array}$ & $\begin{array}{l}\text { What is the most } \\
\text { challenging aspect of } \\
\text { the low carbohydrate } \\
\text { lifestyle? } \\
\text { (1302 responses) }\end{array}$ & $\begin{array}{l}\text { What is the most } \\
\text { important piece of } \\
\text { information or learning } \\
\text { that you have taken from } \\
\text { the low carbohydrate } \\
\text { lifestyle? ( } 1226 \text { responses) }\end{array}$ \\
\hline $\begin{array}{l}\text { Improvement in allergy } \\
\text { symptoms and breathing } \\
\text { quality }\end{array}$ & $\begin{array}{l}\text { Holidays and special } \\
\text { occasions }\end{array}$ & $\begin{array}{l}\text { Insulin resistance and } \\
\text { metabolic syndrome }\end{array}$ \\
\hline $\begin{array}{l}\text { Improvement in athletic } \\
\text { performance }\end{array}$ & Vacations and travelling & Sugar content of food \\
\hline Improvement in libido & $\begin{array}{l}\text { Social occasions and } \\
\text { dining out }\end{array}$ & Food's effect on satiety \\
\hline $\begin{array}{l}\text { Improvement in mental } \\
\text { clarity }\end{array}$ & $\begin{array}{l}\text { Negative reactions } \\
\text { from family and friends }\end{array}$ & Self-importance \\
\hline $\begin{array}{l}\text { Improvement in irritable } \\
\text { bowel syndrome }\end{array}$ & $\begin{array}{l}\text { Negative reactions from } \\
\text { health professionals }\end{array}$ & $\begin{array}{l}\text { Importance of non-scale } \\
\text { victories }\end{array}$ \\
\hline $\begin{array}{l}\text { Improvement in } \\
\text { heartburn and acid reflux }\end{array}$ & $\begin{array}{l}\text { Criticism and } \\
\text { misunderstanding }\end{array}$ & $\begin{array}{l}\text { Eating fat does not cause } \\
\text { you to be fat }\end{array}$ \\
\hline $\begin{array}{l}\text { Improvement in immune } \\
\text { function }\end{array}$ & $\begin{array}{l}\text { Initial 'carbohydrate flu' } \\
\text { symptoms }\end{array}$ & $\begin{array}{l}\text { Eating three meals a day is } \\
\text { unnecessary }\end{array}$ \\
\hline $\begin{array}{l}\text { Improvement in integument } \\
\text { and dental quality }\end{array}$ & $\begin{array}{l}\text { Leg cramps and } \\
\text { electrolyte balance }\end{array}$ & $\begin{array}{l}\text { Nutritional ketosis is } \\
\text { different from ketoacidosis }\end{array}$ \\
\hline $\begin{array}{l}\text { Improvement in polycystic } \\
\text { ovary syndrome and } \\
\text { menstruation }\end{array}$ & $\begin{array}{l}\text { Work, financial and } \\
\text { other life stressors }\end{array}$ & $\begin{array}{l}\text { Eating meat is not } \\
\text { something to feel guilty } \\
\text { about }\end{array}$ \\
\hline $\begin{array}{l}\text { Improvement in migraine } \\
\text { frequency }\end{array}$ & $\begin{array}{l}\text { Concerns about } \\
\text { cholesterol }\end{array}$ & $\begin{array}{l}\text { To pay attention to how one } \\
\text { feels in response to food }\end{array}$ \\
\hline $\begin{array}{l}\text { Improvement in joint pain } \\
\text { and chronic pain }\end{array}$ & Desire for certain foods & $\begin{array}{l}\text { Carbs are not needed to } \\
\text { train for endurance races }\end{array}$ \\
\hline Improvement in NAFLD & None & $\begin{array}{l}\text { Sugar cravings occur only } \\
\text { when eating sugar }\end{array}$ \\
\hline
\end{tabular}

NAFLD, non-alcoholic fatty liver disease.

an undiluted view of what is possible when a lowcarbohydrate approach is successful. The reversals in lab values, body weight and waist circumference that were reported in the survey are striking. In addition, reductions in medication use, pain and mental health concerns along with improved energy and mobility after diet initiation were commonly reported. As would be expected with such improvements in physical health, the cohort reported overwhelmingly that their physical and psychological wellbeing also improved after starting a low-carbohydrate diet.

\section{Discussion of key findings}

An important marker of metabolic health and adverse longterm outcomes is a large waist circumference and visceral fat. ${ }^{81,82}$ Although we had to rely on participants' self-report of pounds and inches gained or lost, in light of the fact that sustained weight loss is universally difficult, our dramatic findings deserve consideration. A weight loss of 20 pounds or more was reported by $65.1 \%$ of those on the diet for $6-12$ months and by $58.8 \%$ of those on the diet for 2 years or more (Figure 2).

Although fewer than half $(44.1 \%)$ of respondents reported that their reason for following a low-carbohydrate diet was to improve a chronic condition, we collected robust data for diabetes and glucose control. Of the entire cohort, $495 \mathrm{knew}$ their $\mathrm{HbA} 1 \mathrm{c}$ before diet initiation and $413 \mathrm{knew}$ their value post-diet initiation. By definition, people with T2D have an $\mathrm{HbA} 1 \mathrm{c}$ of $\geq 6.5$, and pre-diabetes is defined by an $\mathrm{HbA} 1 \mathrm{c}$ of 5.7-6.4. Many studies suggest that an $\mathrm{HbA} 1 \mathrm{c}$ around 5.0-5.5 is likely to be the ideal. ${ }^{83,84,85,86}$ Of those reporting their afterinitiation values, the proportion with an $\mathrm{HbA} 1 \mathrm{c}<6.5$ nearly doubled, and nearly four times as many reported an $\mathrm{HbA} 1 \mathrm{c}$ of $<5.5$. Most importantly, those with an $\mathrm{HbA1c}$ in the diabetic range $(\geq 6.5$ ) decreased from $48.5 \%$ to $7.1 \%$.

Active management of diabetes requires measuring fasting and post-meal blood glucose levels. Average pre-diet values (143 mg/dL fasting and $175 \mathrm{mg} / \mathrm{dL}$ post-meal) reflected poor glucose tolerance (Table 3). At the time of the survey, the average blood glucose values were $99 \mathrm{mg} / \mathrm{dL}$ for fasting and $107 \mathrm{mg} / \mathrm{dL}$ for post-meal, which is a significant improvement.

It is clear in the literature that the most powerful predictor in a basic lipid panel of insulin resistance and cardiovascular health is the ratio of TG and HDL-cholesterol. ${ }^{87,88,89,90}$ As lowdensity lipoprotein (LDL) cholesterol (which is calculated as the measurement of cholesterol mass within LDL particles) is made up of small (atherogenic) and large (healthy) particles, there is controversy about total LDL role as a predictor of cardiovascular events. ${ }^{74}$ A low TG/HDL ratio reflects 'pattern $A^{\prime}$ (large LDL particles) and a high TG/HDL ratio reflects 'pattern $\mathrm{B}^{\prime}$ (small LDL particles), the latter being more closely associated with both carbohydrate (particularly refined) intake and cardiovascular disease risk. ${ }^{90,91}$ Because of its association with a less atherogenic lipid profile, a TG/HDL ratio close to 1.0 is regarded as predictive of low cardiovascular risk. ${ }^{92}$ A higher TG/HDL ratio is also associated with hyperinsulinaemia, ${ }^{93}$ which is an independent risk factor for cardiovascular disease. ${ }^{94}$ One concern about a low-carbohydrate diet is the typical slight rise in LDL cholesterol, although no study has shown its adverse outcome. Dietary interventions that lower LDL have also failed to show reductions in disease risk. ${ }^{95,96}$ In fact, evidence has shown overall cardiovascular risk to improve on a well-formulated low-carbohydrate diet. ${ }^{97}$ Higher LDL-C has been associated with longevity in one review of 68000 patients. ${ }^{98}$ Among study respondents who knew their values, after starting a low-carbohydrate diet, average HDL increased and average TG decreased. Most significantly, the pre-diet TG/HDL ratio was 3.5. After diet initiation, the average TG/HDL ratio was 1.4 , which reflects a much lower cardiovascular risk.

Our survey showed marked reductions in medication use and costs, which is an important finding not only for consumers but also for insurance companies and taxpayers. While more than half of the respondents said drug costs were not relevant for them, a quarter of respondents were able to reduce their individual costs, and in those with a specific amount cited, the average reduction was $\$ 288$ a month.

Decreased strength and difficulty in mobility are associated with poor health outcomes and increased mortality. ${ }^{99,100,101}$ The ability to rise from the floor and have a strong walking speed is associated with healthy ageing. ${ }^{102}$ The number of survey respondents reporting moderate or severe mobility problems or being unable to walk declined from 278 to 49 individuals after diet initiation, and the number reporting moderate to severe pain declined dramatically after diet 
initiation, from 674 to 78 . It is reasonable to conclude that the reported improvements in mobility were at least in part associated with reductions in pain. Chronic pain is a major reason why patients seek primary care, and our current approach to pain management has resulted in unintended consequences, contributing to the current opioid crisis. ${ }^{103}$ Safe and natural methods for pain management need to be explored, and we are just beginning to learn the potential of nutritional therapy. This finding suggests further work needs to be conducted on dietary interventions for pain.

Similarly, anxiety and depression are common primary care symptoms. ${ }^{104}$ Pharmaceutical management of these conditions has shown marginal benefit (confounded by significant misreporting of trials in the literature), ${ }^{105,106}$ especially in those with mild or moderate symptoms where dietary or lifestyle interventions are likely to have a greater impact. ${ }^{107,108}$ Antidepressant medications also carry significant side effects, especially in elderly patients already under a burden of iatrogenic polypharmacy. ${ }^{109}$ Our survey respondents reported marked improvements in symptoms of anxiety and depression after starting a low-carbohydrate diet. These findings support low-carbohydrate nutrition as an alternative therapeutic approach for some mental health conditions and warrant continued research. ${ }^{110}$ How one feels between meals in mood and cravings is also critical to sustain any nutritional lifestyle plan. One well-known claim of lowcarbohydrate diets is that one can lose weight and not be hungry. ${ }^{111,112,113}$ Our survey respondents, more than one-third of whom had been on a low-carbohydrate diet over 2 years, strongly affirmed this. Table 10 shows the dramatic differences before and after low-carbohydrate diet initiation in self-reported symptoms of hunger, fatigue, poor concentration, mood swings, blood sugar swings, irritability and anxiety. Furthermore, participants also reported an increase in energy levels despite the lower caloric intake that naturally occurs with a low-carbohydrate diet. ${ }^{114}$

In this sample of successful, mostly long-term lowcarbohydrate diet followers, the diet led to improvements in physical and psychological well-being for most of our study respondents. Feelings of emotional well-being are hypothesised to be important components for sustainable lifestyle change. ${ }^{115}$ These overwhelmingly positive changes suggest that a low-carbohydrate diet may be especially sustainable. In addition, $18 \%$ of participants reported no regular physical activity, supporting the idea that people do not need to exercise excessively to lose fat and improve metabolism.

Moreover, participants reported improvements in a variety of health conditions after initiating a low-carbohydrate diet, some of which have been studied before, at least preliminarily (improvements in symptoms related to migraines, ${ }^{116}$ irritable bowel syndrome, ${ }^{117}$ heartburn, ${ }^{118}$ polycystic ovary syndrome, ${ }^{119}$ NAFLD $^{120}$ and pain $\left.{ }^{121}\right)$, and some of which have not been studied well or much at all (e.g., libido, immune function and allergies). More research is needed on these topics.

\section{Limitations}

This study was not without limitations. This was a retrospective study assessing a host of biomedical indicators reliant on self-reported data subject to recall bias. Although we believe that the questions we used are face valid, we did not use validated self-report scales. Therefore, some answers may not be as reliable and accurate as they would have been if we had used validated instruments. A detailed survey like this also lends itself to those who are highly engaged in the topic. Like any survey, the respondents may not be representative of all patients. Furthermore, in our appeal for participants, we did not differentiate between people who are followers of one of the many types of carbohydraterestricted approaches such as low-carbohydrate, high-fat and low-carbohydrate, high-protein (although most of the practitioners who supported the survey favoured a lowcarbohydrate, high-fat approach). As to the small sample of minorities, we feel this reflects, at least in part, the bias inherent in snowballing sampling. Many of the initial contacts when the survey was launched were not minority (non-white people comprise about $6 \%$ of the population of the state of West Virginia). As the survey was largely shared through social networks, it could be that race played a role in who was invited to take part.

Furthermore, this study lacked the rigour of a randomised, controlled trial. However, our goal was not to compare the results of a low-carbohydrate diet with some other dietary approach. Instead, we were interested in what people who were voluntarily choosing to follow some kind of carbohydrate-reduced nutritional approach would report about their lived experience.

\section{Implications}

The results of our survey support pursuit of other pertinent questions around myriad aspects of low-carbohydrate diets: long-term health effects, factors that facilitate success and overcoming of barriers, age-related differences in response to the diet and parameters of the optimal low-carbohydrate diet for overall health and well-being.

\section{Conclusion}

Currently recommended drug treatments, nutritional guidelines and behavioural interventions have had limited to no success in halting the obesity and diabetes epidemics. This has resulted in exorbitant health care costs ${ }^{122}$ and indirect costs from lower quality of life ${ }^{123}$ and lost productivity ${ }^{124}$ for a growing proportion of the population. The premise of this research project is that excess carbohydrate intake in the Western diet is a major driver of the obesity and diabetes epidemics, and that restricting dietary carbohydrate to a level that permits utilisation of fat as the primary fuel will yield substantial weight loss and improvement in diabetes and metabolic syndrome, other health conditions and overall quality of life. Moreover, we show that for many, a lowcarbohydrate diet is satisfying and sustainable. 


\section{Acknowledgements Competing interests}

The authors declare that they have no financial or personal relationships which may have inappropriately influenced them in writing this article.

\section{Authors' contributions}

M.T.C. was responsible for project conception, design and implementation. J.T. assisted with project implementation, performed calculations and created figures and graphs. M.T.C. and J.T. wrote the initial draft. N.E.D. made conceptual and editorial contributions. L.S. was responsible for the aims section and made conceptual and editorial contributions. T.R.W. made conceptual and editorial contributions and reviewed calculations as well as directed the reference section.

\section{References}

1. CDC. National diabetes statistics report, 2017. Atlanta GA: Centers for Disease Control and Prevention, US Department of Health and Human Services; 2017.

2. Brinkworth GD, Noakes M, Buckley JD, Keogh JB, Clifton PM. Long-term effects of a very-low-carbohydrate weight loss diet compared with an isocaloric low-fat diet after 12 mo. Am J Clin Nutr. 2009;90:23-32. https://doi.org/10.3945/ajcn.2008.27326

3. Ogden $\mathrm{CL}$ Carroll MD, Fryar CD, Flegal KM. Prevalence of obesity among adults and youth: United States, 2011-2014. NCHS data brief, no 219. Hyattsville, MD: National Center for Health Statistics; 2015.

4. Flegal KM, Kruszon-Moran D, Carroll MD, Fryar CD, Ogden CL. Trends in obesity among adults in the United States, 2005 to 2014. JAMA. 2016;315:2284-2291. https://doi.org/10.1001/jama.2016.6458

5. Manninen AH. Metabolic effects of the very-low-carbohydrate diets: Misunderstood 'villains' of human metabolism. J Int Soc Sports Nutr. 2004;1:7-11. https://doi.org/10.1186/1550-2783-1-2-7

6. Wang $L$, Gao P, Zhang $M$, et al. Prevalence and ethnic pattern of diabetes and prediabetes in China in 2013. JAMA. 2017;317:2515-2523. https://doi. org/10.1001/jama.2017.7596

7. Dall TM, Yang W, Halder P, et al. The economic burden of elevated blood glucose levels in 2012: Diagnosed and undiagnosed diabetes, gestational diabetes mellitus, and prediabetes. Diabetes Care. 2014;37:3172-3179. https://doi. org/10.2337/dc14-1036

8. American Diabetes Association. Economic costs of diabetes in the U.S. in 2012. Diabetes Care. 2013;36:1033-1046. https://doi.org/10.2337/dc12-2625

9. The state of obesity - West Virginia [homepage on the Internet]. 2016 [cited 2017 Sept 14]. Available from: https://stateofobesity.org/states/wv

10. Menke A, Casagrande S, Geiss L, Cowie CC. Prevalence of and trends in diabetes among adults in the United States, 1988-2012. JAMA. 2015;314:1021-109. https://doi.org/10.1001/jama.2015.10029

11. Buse JB, Caprio S, Cefalu WT, et al. How do we define cure of diabetes? Diabetes Care. 2009;32:2133-2135. https://doi.org/10.2337/dc09-9036

12. Olefsky J, Farquhar JW, Reaven G. Relationship between fasting plasma insulin level and resistance to insulin-mediated glucose uptake in normal and diabetic subjects. Diabetes. 1973;22:507-513. https://doi.org/10.2337/diab.22.7.507

13. McKenzie AL, Hallberg SJ, Creighton BC, et al. A novel intervention including individualized nutritional recommendations reduces hemoglobin $A 1 \mathrm{c}$ level, medication use, and weight in type 2 diabetes. JMIR Diabetes. 2017;2:e5. https:// doi.org/10.2196/diabetes.6981

14. Mozumdar A, Liguori G. Persistent increase of prevalence of metabolic syndrome among U.S. adults: NHANES III to NHANES 1999-2006. Diabetes Care. 2011;34:216-219. https://doi.org/10.2337/dc10-0879

15. Gami AS, Witt BJ, Howard DE, et al. Metabolic syndrome and risk of incident cardiovascular events and death. J Am Coll Cardiol. 2007;49:403-414. https://doi. org/10.1016/j.jacc.2006.09.032

16. Reaven $\mathrm{G}$. Insulin resistance and coronary heart disease in nondiabetic individuals. Arterioscler Thromb Vasc Biol. 2012;32:1754-1759. https://doi.org/10.1161/ ATVBAHA.111.241885

17. Esser N, Legrand-Poels S, Piette J, Scheen AJ, Paquot N. Inflammation as a link between obesity, metabolic syndrome and type 2 diabetes. Diabetes Res Clin Pract. 2014;105:141-150. https://doi.org/10.1016/j.diabres.2014.04.006

18. Tziomalos K, Athyros VG, Karagiannis A, Mikhailidis DP. Endothelial dysfunction in metabolic syndrome: Prevalence, pathogenesis and management. Nutr Metab Cardiovasc Dis. 2010;20:140-146. https://doi.org/10.1016/j.numecd.2009.08.006

19. Williams T. Metabolic syndrome: Nonalcoholic fatty liver disease. FP Essent. 2015;435:24-29.
20. Essah PA, Wickham EP, Nestler JE. The metabolic syndrome in polycystic ovary syndrome. Clin Obstet Gynecol. 2007:50:205-225. https://doi.org/10.1097/ GRF.0b013e31802f3547

21. Calvin AD, Albuquerque FN, Lopez-Jimenez F, Somers VK. Obstructive sleep apnea, inflammation, and the metabolic syndrome. Metab Syndr Relat Disord. 2009;7:271-277. https://doi.org/10.1089/met.2008.0093

22. Esposito K, Chiodini P, Colao A, Lenzi A, Giugliano D. Metabolic syndrome and risk of cancer: A systematic review and meta-analysis. Diabetes Care. 2012;35:24022411. https://doi.org/10.2337/dc12-0336

23. Ng TP, Feng L, Nyunt MS, et al. Metabolic syndrome and the risk of mild cognitive impairment and progression to dementia: Follow-up of the Singapore longitudinal ageing study cohort. JAMA Neurol. 2016;73:456-463. https://doi.org/10.1001/ jamaneurol.2015.4899

24. Solfrizzi V, Scafato E, Capurso C, et al. Metabolic syndrome, mild cognitive impairment, and progression to dementia. The Italian Longitudinal Study on Aging. Neurobiol Aging. 2011;32:1932-1941. https://doi.org/10.1016/j. neurobiolaging.2009.12.012

25. Rosen Evan D, Spiegelman Bruce M. What we talk about when we talk about fat. Cell. 2014;156:20-44. https://doi.org/10.1016/j.cell.2013.12.012

26. Kim JI, Huh JY, Sohn JH, et al. Lipid-overloaded enlarged adipocytes provoke insulin resistance independent of inflammation. Mol Cell Biol. 2015;35:16861699. https://doi.org/10.1128/MCB.01321-14

27. Crofts CAP, Zinn C, Wheldon M, Schofield G. Hyperinsulinemia: A unifying theory of chronic disease? Diabesity. 2015;1(4):34-43. https://doi.org/10.15562/ diabesity.2015.19

28. Williams KJ, Wu X. Imbalanced insulin action in chronic over nutrition: Clinical harm, molecular mechanisms, and a way forward. Atherosclerosis. 2016;247:225282. https://doi.org/10.1016/j.atherosclerosis.2016.02.004

29. Makki K, Froguel P, Wolowczuk I. Adipose tissue in obesity-related inflammation and insulin resistance: Cells, cytokines, and chemokines. ISRN Inflamm. 2013;2013:139239. https://doi.org/10.1155/2013/139239

30. Perry Rachel J, Camporez J-PG, Kursawe R, et al. Hepatic acetyl CoA links adipose tissue inflammation to hepatic insulin resistance and type 2 diabetes. Cell. 2015;160:745-758. https://doi.org/10.1016/j.cell.2015.01.012

31. Magnusson I, Rothman DL, Katz LD, Shulman RG, Shulman GI. Increased rate of gluconeogenesis in type $\|$ diabetes mellitus. A 13 C nuclear magnetic resonance study. J Clin Invest. 1992;90:1323-1327. https://doi.org/10.1172/JCl115997

32. U.K. Prospective Diabetes Study 16: Overview of 6 years' therapy of type I diabetes: A progressive disease. Diabetes. 1995;44:1249-1258. https://doi. org/10.2337/diab.44.11.1249

33. American Diabetes Association. (2) Classification and diagnosis of diabetes Diabetes Care. 2015;38:S8-S16. https://doi.org/10.2337/dc15-S005

34. Soumya D, Srilatha B. Late stage complications of diabetes and insulin resistance. J Diabetes Metab. 2011;2:167. https://doi.org/10.4172/2155-6156.1000167

35. Introduction. Diabetes Care. 2017;40:S1-S2. https://doi.org/10.2337/dc17-S001

36. Evert AB, Boucher JL, Cypress M, et al. Nutrition therapy recommendations for the management of adults with diabetes. Diabetes Care. 2013;36:3821-3842. https:// doi.org/10.2337/dc13-2042

37. Karter AJ, Nundy S, Parker MM, Moffet HH, Huang ES. Incidence of remission in adults with type 2 diabetes: The diabetes \& aging study. Diabetes Care. 2014;37:3188-3195. https://doi.org/10.2337/dc14-0874

38. Gerstein HC, Miller ME, Byington RP, et al. Effects of intensive glucose lowering in type 2 diabetes. N Engl J Med. 2008;358:2545-2559. https://doi.org/10.1056/ NEJMoa0802743

39. Zoungas S, Chalmers J, Neal B, et al. Follow-up of blood-pressure lowering and glucose control in type 2 diabetes. N Engl J Med. 2014;371:1392-1406. https:// doi.org/10.1056/NEJMoa1407963

40. Hayward RA, Reaven PD, Wiitala WL, et al. Follow-up of glycemic control and cardiovascular outcomes in type 2 diabetes. N Engl J Med. 2015;372:2197-2206. https://doi.org/10.1056/NEJMoa1414266

41. Gerstein HC, Bosch J, Dagenais GR, et al. Basal insulin and cardiovascular and other outcomes in dysglycemia. N Engl J Med. 2012;367:319-328. https://doi org/10.1056/NEJMoa1203858

42. Green JB, Bethel MA, Armstrong PW, et al. Effect of sitagliptin on cardiovascular outcomes in type 2 diabetes. N Engl J Med. 2015;373:232-242. https://doi. org/10.1056/NEJMoa1501352

43. Hirshberg B, Katz A. Insights from cardiovascular outcome trials with nove antidiabetes agents: What have we learned? An industry perspective. Curr Diab antidiabetes agents: What have we learned? An industry perspe
Rep. 2015;15:87. https://doi.org/10.1007/s11892-015-0663-9

44. Scirica BM, Bhatt DL, Braunwald E, et al. Saxagliptin and cardiovascular outcomes in patients with type 2 diabetes mellitus. N Engl J Med. 2013;369:1317-1326. https://doi.org/10.1007/s11892-015-0663-9

45. Banting W. Letter on corpulence. Washington, DC: U.S. National Library of Medicine; 1984.

46. Taubes G. Good calories, bad calories. New York: Anchor Bookis, Random House, Inc.; 2008.

47. Sacks FM, Lichtenstein AH, Wu JHY, et al. Dietary fats and cardiovascular disease: A presidential advisory from the American Heart Association. Circulation. 2017;136(10):e195. https://doi.org/10.1161/CIR.0000000000000510

48. Dehghan $M$, Mente $A$, Zhang $X$, et al. Associations of fats and carbohydrate intake with cardiovascular disease and mortality in 18 countries from five continents (PURE): A prospective cohort study. Lancet. 2017;390:2050-2062. https://doi. org/10.1016/S0140-6736(17)32252-3 
49. Harcombe Z, Baker JS, Cooper SM, et al. Evidence from randomised controlled trials did not support the introduction of dietary fat guidelines in 1977 and 1983 : A systematic review and meta-analysis. Open Heart. 2015;2:e000196. https://doi. A systematic review and meta-analysis.
org/10.1136/openhrt-2014-000196

50. Chowdhury R, Warnakula S, Kunutsor S, et al. Association of dietary, circulating, and supplement fatty acids with coronary risk: A systematic review and metaanalysis. Ann Intern Med. 2014;160:398-406. https://doi.org/10.7326/M13-1788

51. Siri-Tarino PW, Sun Q, Hu FB, Krauss RM. Meta-analysis of prospective cohort studies evaluating the association of saturated fat with cardiovascular diseas

Am J Clin Nutr. 2010;91:535-546. https://doi.org/10.3945/ajcn.2009.27725

52. De Souza RJ, Mente A, Maroleanu A, et al. Intake of saturated and trans unsaturated fatty acids and risk of all cause mortality, cardiovascular disease, and BMJ. 2015;351:h3978. https://doi.org/10.1136/bmj.h3978

53. Hamley S. The effect of replacing saturated fat with mostly $n-6$ polyunsaturated fat on coronary heart disease: A meta-analysis of randomised controlled trials. Nutr J. 2017;16:30. https://doi.org/10.1186/s12937-017-0254-5

54. Tobias DK, Chen M, Manson JE, Ludwig DS, Willett W, Hu FB. Effect of low-fat die interventions versus other diet interventions on long-term weight change in adults: A systematic review and meta-analysis. Lancet Diabetes Endocrinol. 2015;3:968-979. https://doi.org/10.1016/\$2213-8587(15)00367-8

55. Feinman RD, Pogozelski WK, Astrup A, et al. Dietary carbohydrate restriction as the first approach in diabetes management: Critical review and evidence base. Nutrition. 2015;31:1-13. https://doi.org/10.1016/j.nut.2014.06.011

56. Volek JS, Phinney SD, Forsythe $\mathrm{CE}$, et al. Carbohydrate restriction has a more favorable impact on the metabolic syndrome than a low fat diet. Lipids. 2009;44:297-309. https://doi.org/10.1007/s11745-008-3274-2

57. Hjorth MF, Ritz C, Blaak EE, et al. Pretreatment fasting plasma glucose and insulin modify dietary weight loss success: Results from 3 randomized clinical trials. Am J Clin Nutr. 2017;106:499-505. https://doi.org/10.3945/ajcn.117.155200

58. Saslow LR, Mason AE, Kim S, et al. An online intervention comparing a very lowcarbohydrate ketogenic diet and lifestyle recommendations versus a plate method diet in overweight individuals with type 2 diabetes: A randomized controlled trial. J Med Internet Res. 2017;19:e36. https://doi.org/10.2196/jmir.5806

59. Hu T, Yao L, Reynolds K, et al. The effects of a low-carbohydrate diet vs. a low-fat diet on novel cardiovascular risk factors: A randomized controlled trial. Nutrients. diet on novel cardiovascular risk factors: A randomized co
2015;7:7978-7994. https://doi.org/10.3390/nu7095377

60. Perez-Guisado J, Munoz-Serrano A, Alonso-Moraga A. Spanish ketogenic Mediterranean diet: A healthy cardiovascular diet for weight loss. Nutr J. 2008;7:30. https://doi.org/10.1186/1475-2891-7-30

61. Sackner-Bernstein J, Kanter D, Kaul S. Dietary intervention for overweight and obese adults: Comparison of low-carbohydrate and low-fat diets. A meta-analysis. PLoS One. 2015;10:e0139817. https://doi.org/10.1371/journal.pone.0139817

62. Westman EC, Feinman RD, Mavropoulos JC, et al. Low-carbohydrate nutrition and metabolism. Am J Clin Nutr. 2007;86:276-284.

63. Volek JS, Feinman RD. Carbohydrate restriction improves the features of metabolic syndrome. Metabolic syndrome may be defined by the response to carbohydrate restriction. Nutr Metab. 2005;2:31. https://doi.org/10.1186/1743-7075-2-31

64. Gardner CD, Kiazand A, Alhassan S, et al. Comparison of the Atkins, Zone, Ornish, and LEARN diets for change in weight and related risk factors among overweight premenopausal women: The A to Z weight loss study: A randomized trial. JAMA 2007;297:969-977. https://doi.org/10.1001/jama.297.9.969

65. Shai I, Schwarzfuchs D, Henkin Y, et al. Weight loss with a low-carbohydrate, Mediterranean, or low-fat diet. N Engl J Med. 2008;359:229-241. https://doi. org/10.1056/NEJMoa0708681

66. Guldbrand H, Dizdar B, Bunjaku B, et al. In type 2 diabetes, randomisation to advice to follow a low-carbohydrate diet transiently improves glycaemic control
compared with advice to follow a low-fat diet producing a similar weight loss. compared with advice to follow a low-fat diet producing a similar weight loss.
Diabetologia. 2012;55:2118-2127. https://doi.org/10.1007/s00125-012-2567-4

67. Bazzano LA, Hu T, Reynolds K, et al. Effects of low-carbohydrate and low-fat diets: A randomized trial. Ann Intern Med. 2014;161:309-318. https://doi.org/10.7326/ M14-0180

68. Foster GD, Wyatt HR, Hill JO, et al. Weight and metabolic outcomes after 2 years on a low-carbohydrate versus low-fat diet: A randomized trial. Ann Intern Med. 2010;153:147-157. https://doi.org/10.7326/0003-4819-153-3-201008030-00005

69. Stern L, Iqbal N, Seshadri $P$, et al. The effects of low-carbohydrate versus conventional weight loss diets in severely obese adults: One-year follow-up of a randomized trial. Ann Intern Med. 2004;140:778-785. https://doi.org/10.7326/ 0003-4819-140-10-200405180-00007

70. Tay J, Luscombe-Marsh ND, Thompson CH, et al. Comparison of low- and highcarbohydrate diets for type 2 diabetes management: A randomized trial. Am J Clin Nutr. 2015;102:780-790. https://doi.org/10.3945/ajcn.115.112581

71. Sondike SB, Copperman N, Jacobson MS. Effects of a low-carbohydrate diet on weight loss and cardiovascular risk factor in overweight adolescents. J Pediatr. 2003;142:253-258. https://doi.org/10.1067/mpd.2003.4

72. Kersten S. Mechanisms of nutritional and hormonal regulation of lipogenesis. EMBO Rep. 2001;2:282-286. https://doi.org/10.1093/embo-reports/kve071

73. Mansoor N, Vinknes KJ, Veierod MB, Retterstol K. Effects of low-carbohydrate diets v. low-fat diets on body weight and cardiovascular risk factors: A metaanalysis of randomised controlled trials. Br J Nutr. 2016;115:466-479. https://doi. org/10.1017/S0007114515004699

74. Wood TR, Hansen R, Sigurethsson AF, Johannsson GF. The cardiovascular risk reduction benefits of a low-carbohydrate diet outweigh the potential increase in
LDL-cholesterol. Br J Nutr. 2016;115:1126-1128. https://doi.org/10.1017/ S0007114515005450

75. Noakes TD. Low-carbohydrate and high-fat intake can manage obesity and associated conditions: Occasional survey. S Afr Med J. 2013;103:826-830. https:// doi.org/10.7196/SAMJ.7302

76. Feinman RD, Vernon MC, Westman EC. Low carbohydrate diets in family practice: What can we learn from an internet-based support group. Nutr J. 2006;5:26 https://doi.org/10.1186/1475-2891-5-26

77. Paleo and low carb, 52 countries strong [homepage on the Internet]. 2013 [cited 2017 Aug 20]. Available from: http://www.awlr.org/results-2013.html

78. Phelan S, Wyatt $H$, Nassery $S$, et al. Three-year weight change in successful weight losers who lost weight on a low-carbohydrate diet. Obesity (Silver Spring, MD). 2007;15:2470-2477. https://doi.org/10.1038/oby.2007.293

79. Atkins RD. Dr. Atkins' new diet revolution. New York: HarperCollins; 2002.

80. Nielsen JV, Joensson E. Low-carbohydrate diet in type 2 diabetes. Stable improvement of bodyweight and glycemic control during 22 months follow-up. Nutr Metab (Lond). 2006;3:22. https://doi.org/10.1186/1743-7075-3-22

81. Cerhan JR, Moore SC, Jacobs EJ, et al. A pooled analysis of waist circumference and mortality in 650,000 adults. Mayo Clin Proc. 2014;89:335-345. https://doi. org/10.1016/j.mayocp.2013.11.011

82. McSweeney JC, Rosenfeld AG, Abel WM, et al. Preventing and experiencing ischemic heart disease as a woman: State of the science: A statement for healthcare professionals from the American Heart Association. Circulation. 2016;133:1302-1331. https://doi.org/10.1161/CIR.0000000000000381

83. Schöttker B, Rathmann W, Herder C, et al. $\mathrm{HbA}(1 \mathrm{c})$ levels in non-diabetic older adults - No J-shaped associations with primary cardiovascular events, cardiovascular and all-cause mortality after adjustment for confounders in a meta-analysis of individual participant data from six cohort studies. BMC Med. 2016;14:26. https://doi.org/10.1186/s12916-016-0570-1

84. Zhong GC, Ye MX, Cheng JH, Zhao Y, Gong JP. HbA1C and risks of all-cause and cause-specific death in subjects without known diabetes: A dose-response metaanalysis of prospective cohort studies. Sci Rep. 2016;6:24071. https://doi. org/10.1038/srep24071

85. Selvin E, Steffes MW, Zhu H, et al. Glycated hemoglobin, diabetes, and cardiovascular risk in nondiabetic adults. N Engl J Med. 2010;362:800-811. https://doi.org/10.1056/NEJMoa0908359

86. Pai JK, Cahill LE, Hu FB, Rexrode KM, Manson JE, Rimm EB. Hemoglobin A Is associated with increased risk of incident coronary heart disease among apparently healthy, nondiabetic men and women. J Am Heart Assoc. 2013;2:e000077. https://doi.org/10.1161/JAHA.112.000077

87. Gaziano JM, Hennekens $\mathrm{CH}$, O’Donnell CJ, Breslow JL, Buring JE. Fasting triglycerides, high-density lipoprotein, and risk of myocardial infarction. Circulation. 1997;96:2520-2525. https://doi.org/10.1161/01.CIR.96.8.2520

88. McLaughlin T, Abbasi F, Cheal K, Chu J, Lamendola C, Reaven G. Use of metabolic markers to identify overweight individuals who are insulin resistant. Ann Intern Med. 2003;139:802-809. https://doi.org/10.7326/0003-4819-139-10200311180-00007

89. Da Luz PL, Favarato D, Junior J, Lemos P, Chagas ACP. High ratio of triglycerides to HDL-cholesterol predicts extensive coronary disease. Clinics. 2008;63:427-432.

90. Krauss RM, Siri PW. Metabolic abnormalities: Triglyceride and low-density lipoprotein. Endocrinol Metab Clin North Am. 2004;33:405-415. https://doi org/10.1016/j.ecl.2004.03.016

91. Siri-Tarino PW, Chiu S, Bergeron N, Krauss RM. Saturated fats versus polyunsaturated fats versus carbohydrates for cardiovascular disease prevention and treatment. Annu Rev Nutr. 2015;35:517-543. https://doi.org/10.1146/ annurev-nutr-071714-034449

92. Boizel R, Benhamou PY, Lardy B, Laporte F, Foulon T, Halimi S. Ratio of triglycerides to $\mathrm{HDL}$ cholesterol is an indicator of LDL particle size in patients with type 2 to $\mathrm{HDL}$ cholesterol is an indicator of LDL particle size in patients with type 2
diabetes and normal HDL cholesterol levels. Diabetes Care. 2000;23:1679-1685. diabetes and normal $\mathrm{HDL}$ cholesterol levels.

93. Li C, Ford ES, Meng YX, Mokdad AH, Reaven GM. Does the association of the triglyceride to high-density lipoprotein cholesterol ratio with fasting serum insulin differ by race/ethnicity? Cardiovasc Diabetol. 2008;7:4. https://doi. insulin differ by race/ethnicity
org/10.1186/1475-2840-7-4

94. Despres JP, Lamarche $B$, Mauriege $P$, et al. Hyperinsulinemia as an independent risk factor for ischemic heart disease. N Engl J Med. 1996;334:952-957. https:// doi.org/10.1056/NEJM199604113341504

95. Howard BV, Van Horn L, Hsia J, et al. Low-fat dietary pattern and risk of cardiovascular disease: The women's health initiative randomized controlled dietary modification trial. JAMA. 2006;295:655-666. https://doi.org/10.1001/jama.295.6.655

96. Multiple Risk Factor Intervention Trial. Risk factor changes and mortality results Multiple Risk Factor Intervention Trial Research Group. JAMA. 1982;248:14651477. https://doi.org/10.1001/jama.1982.03330120023025

97. Volek JS, Fernandez ML, Feinman RD, Phinney SD. Dietary carbohydrate restriction induces a unique metabolic state positively affecting atherogenic dyslipidemia, fatty acid partitioning, and metabolic syndrome. Prog Lipid Res. 2008;47:307-318. https://doi.org/10.1016/j.plipres.2008.02.003

98. Ravnskov U, Diamond DM, Hama R, et al. Lack of an association or an inverse association between low-density-lipoprotein cholesterol and mortality in the elderly: A systematic review. BMJ Open. 2016;6:e010401. https://doi.org/ 10.1136/bmjopen-2015-010401

99. Volaklis KA, Halle M, Meisinger C. Muscular strength as a strong predictor of mortality: A narrative review. Eur J Intern Med. 2015;26:303-310. https://doi. org/10.1016/j.ejim.2015.04.013 
100. Stanaway FF, Gnjidic D, Blyth FM, et al. How fast does the grim reaper walk? Receiver operating characteristics curve analysis in healthy men aged 70 and Receiver operating characteristics curve analysis in healthy men
over. BMJ. 2011;343:d7679. https://doi.org/10.1136/bmj.d7679

101. Ruiz JR, Sui $X$, Lobelo $F$, et al. Association between muscular strength and mortality in men: Prospective cohort study. BMJ. 2008;337:92-95. https://doi. org/10.1136/bmj.a439

102. Brito LB, Ricardo DR, Araujo DS, Ramos PS, Myers J, Araujo CG. Ability to sit and rise from the floor as a predictor of all-cause mortality. Eur J Prev Cardiol. 2014;21:892-898. https://doi.org/10.1177/2047487312471759

103. Schneiderhan J, Clauw D, Schwenk TL. Primary care of patients with chronic pain. JAMA. 2017;317:2367-2368. https://doi.org/10.1001/jama. 2017.5787

104. Treating depression and anxiety in primary care. Prim Care Companion J Clin Psychiatry. 2008;10:145-152. https://doi.org/10.4088/PCC.v10n0209

105. Fournier JC, DeRubeis RJ, Hollon SD, et al. Antidepressant drug effects and depression severity: A patient-level meta-analysis. JAMA. 2010;303:47-53. https://doi.org/10.1001/jama.2009.1943

106. Turner EH, Matthews AM, Linardatos E, Tell RA, Rosenthal R. Selective publication of antidepressant trials and its influence on apparent efficacy. N Eng J Med. 2008;358:252-260. https://doi.org/10.1056/NEJMsa065779

107. Goyal M, Singh S, Sibinga EMS, et al. Meditation programs for psychological stress and well-being: A systematic review and meta-analysis. JAMA Intern Med. 2014;174:357-368. https://doi.org/10.1001/jamainternmed.2013.13018

108. Jacka FN, O'Neil A, Opie R, et al. A randomised controlled trial of dietary improvement for adults with major depression (the 'SMILES' trial). BMC Med. 2017;15:23. https://doi.org/10.1186/s12916-017-0791-y

109. Kok RM, Reynolds CF III. Management of depression in older adults: A review. JAMA. 2017;317:2114-2122. https://doi.org/10.1001/jama.2017.5706

110. Bostock ECS, Kirkby KC, Taylor BVM. The current status of the ketogenic diet in psychiatry. Front Psychiatry. 2017;8:43. https://doi.org/10.3389/fpsyt.2017. 00043

111. Nickols-Richardson SM, Coleman MD, Volpe JJ, Hosig KW. Perceived hunger is lower and weight loss is greater in overweight premenopausal women consuming a low-carbohydrate/high-protein vs high-carbohydrate/low-fat diet. Am Diet Assoc. 2005;105:1433-1437. https://doi.org/10.1016/j.jada.2005. 06.025

112. Hu T, Yao L, Reynolds K, et al. The effects of a low-carbohydrate diet on appetite: A randomized controlled trial. Nutr Metab Cardiovasc Dis. 2016;26:476-488. https://doi.org/10.1016/j.numecd.2015.11.011
113. Merra G, Miranda R, Barrucco S, et al. Very-low-calorie ketogenic diet with aminoacid supplement versus very low restricted-calorie diet for preserving muscle mass during weight loss: A pilot double-blind study. Eur Rev Med muscle mass during weight loss:

114. Boden G, Sargrad K, Homko C, Mozzoli M, Stein TP. Effect of a low-carbohydrate diet on appetite, blood glucose levels, and insulin resistance in obese patients with type 2 diabetes. Ann Intern Med. 2005;142:403-411. https://doi. org/10.7326/0003-4819-142-6-200503150-00006

115. Van Cappellen P, Rice EL, Catalino LI, Fredrickson BL. Positive affective processes underlie positive health behaviour change. Psychol Health. 2017:1-21. https:// doi.org/10.1080/08870446.2017.1320798

116. Di Lorenzo C, Coppola G, Sirianni G, et al. Migraine improvement during short lasting ketogenesis: A proof-of-concept study. Eur J Neurol. 2015;22:170-177. https://doi.org/10.1111/ene.12550

117. Austin GL, Dalton $\mathrm{CB}, \mathrm{Hu} \mathrm{Y}$, et al. A very low-carbohydrate diet improves symptoms and quality of life in diarrhea-predominant irritable bowel syndrome. Clin Gastroenterol Hepatol. 2009;7:706-708.e1. https://doi.org/10.1016/j. cgh.2009.02.023

118. Austin GL, Thiny MT, Westman EC, Yancy WS, Shaheen NJ. A very lowcarbohydrate diet improves gastroesophageal reflux and its symptoms. Dig Dis Sci. 2006;51:1307-1312. https://doi.org/10.1007/s10620-005-9027-7

119. Mavropoulos JC, Yancy WS, Hepburn J, Westman EC. The effects of a lowcarbohydrate, ketogenic diet on the polycystic ovary syndrome: A pilot study. Nutr Metab. 2005;2:35. https://doi.org/10.1186/1743-7075-2-35

120. Tendler D, Lin S, Yancy WS, et al. The effect of a low-carbohydrate, ketogenic diet on nonalcoholic fatty liver disease: A pilot study. Dig Dis Sci. 2007;52:589-593. https://doi.org/10.1007/s10620-006-9433-5

121. Masino SA, Ruskin DN. Ketogenic diets and pain. J Child Neurol. 2013;28:9931001. https://doi.org/10.1177/0883073813487595

122. Dieleman JL, Baral R, Birger M, et al. US spending on personal health care and public health, 1996-2013. JAMA. 2016;316:2627-2646. https://doi.org/ 10.1001/jama.2016.16885

123. Jia $\mathrm{H}$, Lubetkin El. The impact of obesity on health-related quality-of-life in the general adult US population. J Public Health. 2005:27:156-164. https://doi. org/10.1093/pubmed/fdi025

124. Gates DM, Succop P, Brehm BJ, Gillespie GL, Sommers BD. Obesity and presenteeism: The impact of body mass index on workplace productivity. Occup Environ Med. 2008;50:39-45. https://doi.org/10.1097/JOM.0b013e31 $815 \mathrm{~d} 8 \mathrm{db} 2$ 


\section{Apppendix 1}

\section{Low Carb Lifestyle Survey}

Thanks for being part of the Low Carb Lifestyle Survey. This is a project for the American Board of Family Physicians and developed in partnership with Dr. Mark Cucuzzella, Professor West Virginia University School of Medicine, and our partners in the United Kingdom [www.diabetes.co.uk]. Your responses to this survey are confidential and will help us learn how to help you and medical professionals as we gain knowledge and experience with the low carbohydrate lifestyle. Thank you for your time to answer the important questions in this survey. Survey will take approximately 10 minutes. Share with others who have adopted the Low Carb Lifestyle to help us understand and evolve in the therapeutic benefits and the challenges.

\section{* 1. What is your gender?}

Female

Male

\section{* 2. What is your age?}

less than 20

20-29

30-39

$40-49$

$50-59$

$60-69$

over 70

\section{* 3. What is your ethnicity? (Please select all that apply.)}

American Indian or Alaskan Native

Asian or Pacific Islander

Black or African American 


\section{Hispanic or Latino \\ White / Caucasian \\ Prefer not to answer \\ Other (please specify)}

* 4. In what country do you currently reside?

United States

Other (please specify)

(2)

5. IF IN THE USA- In what ZIP code is your home located? (enter 5-digit ZIP code; for example, 00544 or 94305$)$.Skip if not in USA

\section{* 6. What is your occupational status?}

Student

Full-time employment

Part-time employment

Currently not working

Retired

* 7. How many months have you been doing the Low Carb Lifestyle?

less than a month

1-3 months

3-6 months

6 months - 1 year

$1-2$ years

More than 2 years

* 8. How did you hear about the Low Carb Lifestyle?

Friend

Family Member

Medical Professional

Community Group

Internet

Book 
Seminar in your Community

Other (please specify)

* 9. Why did you start on Low Carb Lifestyle? You can select more than one answer

Hope to improve a chronic health conditions such as diabetes or high blood pressure

For Weight loss

Enhance athletic performance

To have more energy through the day

A friend or family member was doing this

No specific reason just curious about it

Other (please specify)

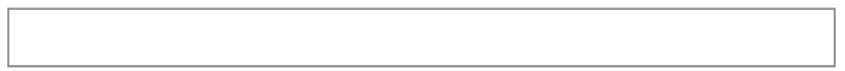

* 10. Do you consider yourself to be currently adherent to a Low Carb Lifestyle?

$\bigcirc$ Yes

No

11. If you stopped the Low Carb Lifestyle- Why?

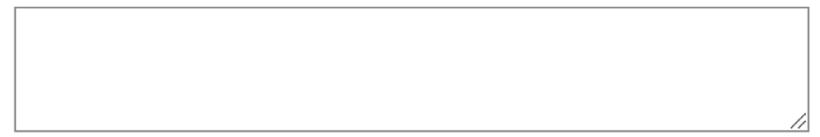

* 12. How many grams of carbohydrate on average do you eat daily ? For an online calculator http://www.carb-counter.org/ . (note- use total carbs not "net" carbs)

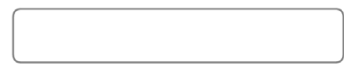

* 13. How many minutes of exercise/physical activity you do per week? If you don't do any physical activity a week, please enter 0 .

* 14. What was your HbA1c before starting Low Carb Lifestyle?

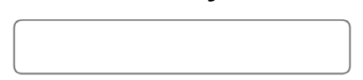

* 15. What is your current HbA1c?

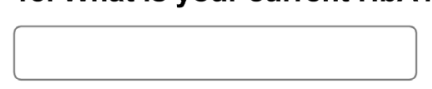

16. What were your cholesterol levels before Low Carb Lifestyle ?

Total cholesterol

(mg/dl): 


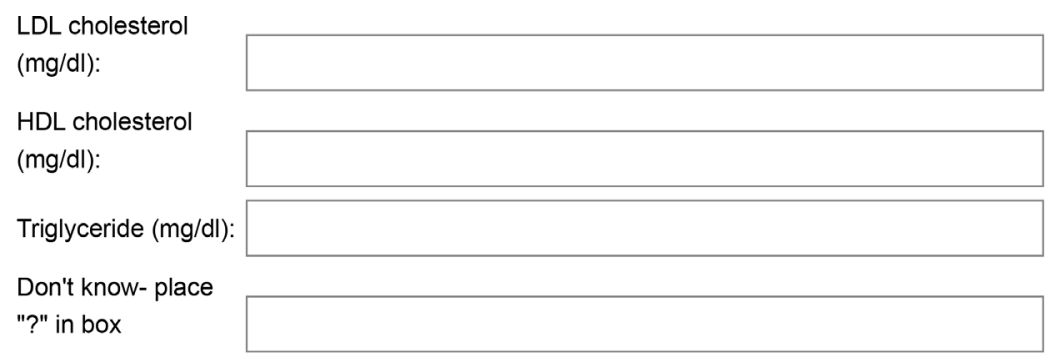

17. What are your current cholesterol levels since starting Low Carb Lifestyle?

Total cholesterol

(mg/dl):

LDL cholesterol

(mg/dl):

HDL cholesterol

(mg/dl):

Triglyceride $(\mathrm{mg} / \mathrm{dl})$ :

Don't know- place

"?" in box
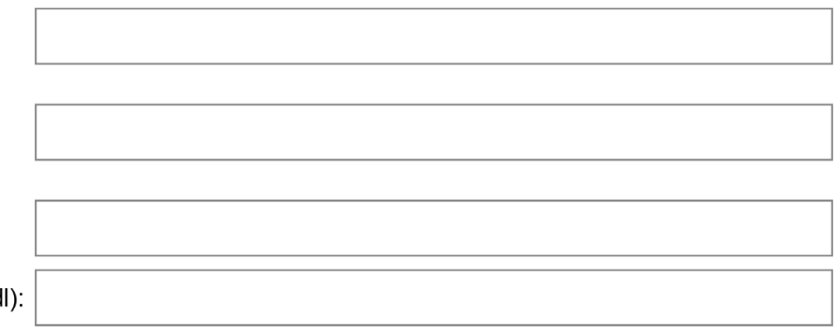

* 18. How has your waist circumference changed since starting Low Carb Lifestyle? instructions on measuring https://www.cdc.gov/healthyweight/assessing/

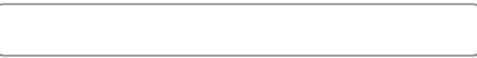

if you have reduced more than 5 inches $/ 12.7 \mathrm{~cm}$ please specify

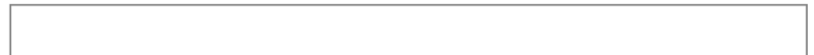

* 19. What units do you use to measure your weight?

Pounds (lbs)

Kilograms $(\mathrm{Kg})$

* 20. Have you lost weight since starting the Low Carb Lifestyle?

$\bigcirc$ Yes

No

* 21. How has your weight changed since starting Low Carb Lifestyle?

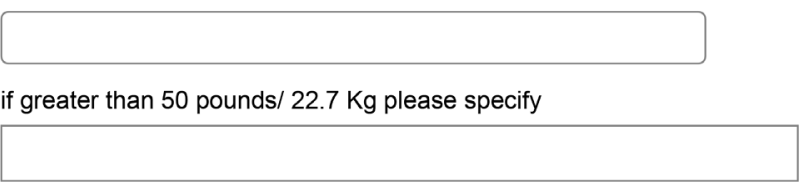

* 22. Did you buy a blood glucose meter to help you on the Low Carb Lifestyle?

Yes

No 
* 23. Did you buy a blood pressure meter to help you on the Low Carb Lifestyle?

Yes

No

No- I already had one

The following questions are on blood glucose monitoring. If you do not check glucose skip to question 27. This data should be available on your meter. If you don't know precisely, just give a rough average.

\section{IF YOU CHECK YOUR BLOOD GLUCOSE- Before starting Low Carb Lifestyle} what was your:

Fasting (morning)

blood glucose level

(mg/dl)

Blood glucose level

1-2 hours after a

typical meal (mg/dl)

25. IF YOU CHECK YOUR BLOOD GLUCOSE- Currently what is your:

Fasting blood

glucose level $(\mathrm{mg} / \mathrm{dl})$

Blood glucose

level 1-2 hours after

a typical meal

$(\mathrm{mg} / \mathrm{dl})$

26. Are you happy with your blood glucose control?

Yes

No

* 27. Do you currently take medication for high blood pressure? (may have more than one answer)

Yes

No

I have come off some/all of my blood pressure medication since starting Low Carb Lifestyle

* 28. Do you currently take medication for high cholesterol? (may have more than one answer)

Yes

No

I have come off some/all of my high cholesterol medication since starting Low Carb Lifestyle 


\section{* 29. Do you currently take medication for diabetes? (may have more than one} answer)

Yes

No

I have come off some/all of my diabetes medication(s) since starting Low Carb Lifestyle

30. Before Low Carb Lifestyle did you regularly take:

Anti-depressants
Anti-anxiety
medication
Sleeping tablets
Painkillers
Anti-inflammatory
medication
$\begin{aligned} & \text { Phosphodiesterase } \\ & \text { type } 5 \text { inhibitors } \\ & \text { (medication for } \\ & \text { erectile } \\ & \text { dysfunction) }\end{aligned}$

31. NOW- Since Starting Low Carb Lifestyle do you regularly take:

Anti-depressants
Anti-anxiety
medication
Sleeping tablets
Painkillers
Anti-inflammatory
Phosphodication
type 5 inhibitors
(medication for
erectile
dysfunction)

* 32. Prior to Low Carb Lifestyle select the option that best describes your mobility:

I had no problems with walking about

I had slight problems with walking about

I had moderate problems with walking about

I had severe problems with walking about

I was unable to walk about 
* 33. NOW - Since starting Low Carb Lifestyle select the option that best describes your mobility :

I have no problems with walking about

I have slight problems with walking about

I have moderate problems with walking about

I have severe problems with walking about

I am unable to walk about

* 34. Prior to Low Carb Lifestyle select the option that best describes your ability to perform your usual activities (e.g. work, study, housework, family or leisure activities):

I had no problems with doing my usual activities

I had slight problems with doing my usual activities

I had moderate problems with doing my usual activities

I had severe problems with doing my usual activities

I was unable to do my usual activities

* 35. NOW- Since starting Low Carb Lifestyle select the option that best describes your ability to perform your usual activities (e.g. work, study, housework, family or leisure activities):

I have no problems with doing my usual activities

I have slight problems with doing my usual activities

I have moderate problems with doing my usual activities

I have severe problems with doing my usual activities

I am unable to do my usual activities

* 36. Prior to Low Carb Lifestyle select the option that best describes your discomfort levels:

I had no pain or discomfort

I had slight pain or discomfort

I had moderate pain or discomfort

I had severe pain or discomfort

I had extreme pain or discomfort

* 37. NOW- Since starting Low Carb Lifestyle select the option that best describes your discomfort levels :

I have no pain or discomfort

I have slight pain or discomfort

I have moderate pain or discomfort

I have severe pain or discomfort 
* 38. Prior to Low Carb Lifestyle select the option that best describes your emotional health:
I was not anxious or depressed
I was slightly anxious or depressed
I was moderately anxious or depressed
I was severely anxious or depressed
I was extremely anxious or depressed

\section{* 39. NOW- Since starting Low Carb Lifestyle select the option that best describes} your emotional health:

I am not anxious or depressed

I am slightly anxious or depressed

I am moderately anxious or depressed

I am severely anxious or depressed

I am extremely anxious or depressed

* 40. How good or bad was your health prior to Low Carb Lifestyle? On a scale of 0 to 100 , where 100 means the best health you can imagine and 0 means the worst health you can imagine:

* 41. How good or bad is your health NOW? On a scale of 0 to 100 , where 100 means the best health you can imagine and 0 means the worst health you can imagine:

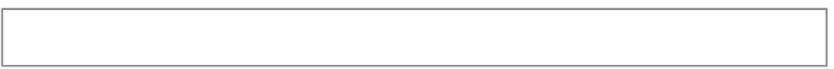

* 42. Prior to Low Carb Lifestyle how would you describe your energy levels :
Low
Moderate
High

* 43. NOW since starting the Low Carb Lifestyle how would you describe your energy levels :
Low
Moderate
High

44. Since starting the Low Carb Lifestyle, how have you found:

$$
\text { Easy Moderately easy Difficult }
$$




Managing changes to
your diet?
Managing changes to
increase your
physical activity?
Managing your
medication(s)? [if
applicable]
Checking your blood
sugar levels? [if
applicable]
Coping
mentallylemotionally?
Knowing what to eat?

* 45. Since starting the Low Carb Lifestyle, what changes have you noticed in your wellbeing:

Quality of life
$\begin{aligned} & \text { Quality of sleep } \\ & \text { improved }\end{aligned}$
$\begin{aligned} & \text { Confidence in } \\ & \text { controlling my } \\ & \text { blood glucose }\end{aligned}$
$\begin{aligned} & \text { levels } \\ & \begin{array}{l}\text { Motivation to } \\ \text { maintain the } \\ \text { changes that }\end{array}\end{aligned}$
$\begin{aligned} & \text { you've made to } \\ & \text { your lifestyle }\end{aligned}$
$\begin{aligned} & \text { Confidence in my } \\ & \text { food choices }\end{aligned}$
$\begin{aligned} & \text { Outlook on life } \\ & \text { Self esteem }\end{aligned}$

* 46. Since starting the Low Carb Lifestyle, do you know:

Yes

which foods a

healthy diet

contains

the different

effects of

carbohydrate,

protein and fat on

my blood glucose

levels 
which foods tend

to contain the

most carbohydrate

alternative recipes

to high-carb

dishes

which foods

contain healthy

fats, and which

contain unhealthy

fats

the difference

between "real"

and "processed"

food

three or more

examples of

healthy, filling

snacks

the effects of

alcoholic drinks on

my blood sugar

levels

what portion

control is

\section{* 47. Prior to the Low Carb Program, on average, how often per week did you:}

\begin{tabular}{|c|c|c|c|c|c|}
\hline & Never & Once per week & $\begin{array}{c}2-3 \text { times per } \\
\text { week }\end{array}$ & $\begin{array}{c}\text { 4-5 times per } \\
\text { week }\end{array}$ & $\begin{array}{c}6+\text { times per } \\
\text { week }\end{array}$ \\
\hline $\begin{array}{l}\text { eat home-cooked } \\
\text { food for dinner } \\
\text { (not a ready meal) }\end{array}$ & & & & & \\
\hline $\begin{array}{l}\text { have takeout for } \\
\text { dinner }\end{array}$ & & & & & \\
\hline $\begin{array}{l}\text { buy your lunch } \\
\text { (rather than } \\
\text { preparing it at } \\
\text { home) }\end{array}$ & & & & & \\
\hline $\begin{array}{l}\text { get } 5 \text { services of } \\
\text { non-starchy } \\
\text { veggies a day }\end{array}$ & & & & & \\
\hline
\end{tabular}

* 48. NOW- Since starting the Low Carb Program, on average, how often per week do you:

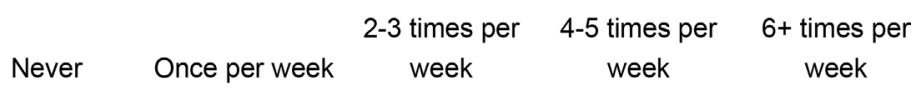

eat home-cooked

food for dinner

(not a ready meal) 


\begin{tabular}{|c|c|c|c|c|c|}
\hline & Never & Once per week & $\begin{array}{l}2-3 \text { times per } \\
\text { week }\end{array}$ & $\begin{array}{l}4-5 \text { times per } \\
\quad \text { week }\end{array}$ & $\begin{array}{c}6+\text { times per } \\
\text { week }\end{array}$ \\
\hline $\begin{array}{l}\text { have takeout for } \\
\text { dinner }\end{array}$ & & & & & \\
\hline $\begin{array}{l}\text { buy your lunch } \\
\text { (rather than } \\
\text { preparing it at } \\
\text { home) }\end{array}$ & & & & & \\
\hline $\begin{array}{l}\text { get } 5 \text { services of } \\
\text { non-starchy } \\
\text { veggies a day }\end{array}$ & & & & & \\
\hline
\end{tabular}

* 49. Prior to the Low Carb Lifestyle, did you regularly experience any of the following between meals?

$\begin{array}{lll}\text { Intense hunger } & \text { Yes } & \text { No } \\ \text { Tiredness } & & \\ \text { Difficulty } \\ \text { concentrating } \\ \begin{array}{l}\text { Spikes in blood } \\ \text { glucose levels }\end{array} & \\ \text { Mood swings } & & \\ \text { Irritability } & \bigcirc & \\ \text { Anxiety } & \bigcirc & \bigcirc\end{array}$

* 50. NOW- Since starting the Low Carb Lifestyle, do you regularly experience any of the following between meals?

$\begin{array}{lll}\text { Intense hunger } & \text { Yes } & \text { No } \\ \text { Tiredness } & & \\ \text { Difficulty } \\ \text { concentrating } \\ \text { Spikes in blood } \\ \text { glucose levels }\end{array}$

51. Have there any been any other changes to your health that we haven't already covered? 
52. What's the most important piece of information or learning that you've taken from the Low Carb Lifestyle?

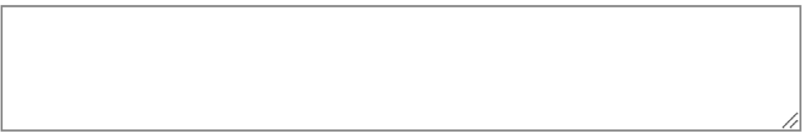

53. What's the most challenging aspect of the Low Carb Lifestyle?

* 54. We want to improve resources for a Low Carb Lifestyle, would any of the following be useful to you? (you can select more than one answer)

Interviews with health professionals

Recipe videos

More recipes

Recipe plans (i.e. a 30 day plan)

The latest research into low-carb

Low carb food lists

More infographics

A mentor to speak to over email

A mentor to speak to over phone

Emotional support

A doctor to ask questions to

Quick and easy low carb foods

I do not need any more resources

* 55. Have you been able to reduce your monthly life insurance premiums by using the Low Carb Lifestyle to improve your health?
Yes
No
Not relevant to me

If so much per month in US Dollars

* 56. Have you been able to reduce your monthly medication costs by using the Low Carb Lifestyle to improve your health?

$\bigcirc$ Yes

No

Not relevant to me

If so how much per month in US Dollars 
57. Thank you for completing the Low Carb Lifestyle Survey. We're looking for low carb champions to support others on their low carb journey and/or case studies for teaching the next generation of medical professionals. If you'd be interested, please leave your email address and/or telephone number and a note of interest. 